\title{
A Group of Jewellery from Diyarbakır Archaeological Museum
}

\author{
[DİYARBAKIR ARKEOLOJI MÜZESI'NDEN BİR GRUP TAKI] \\ Bilcan GÖKCE- Esra KAÇMAZ LEVENT
}

\author{
Anahtar Kelimeler \\ Takı, Nekropol, Süs iğnesi, Fibula, Bilezik, Assur, Kafkasya, Urartu, Iran. \\ Keywords \\ Jewellery, Necropolis, Pin, Fibulae, Bracelet, Assur, Caucasia, Urartu, Iran.
}

\section{ÖZET}

Bu makalede Diyarbakır Müzesi’nde sergilenen süs iğneleri, fibulalar, bizlezikler, metal halka boyunluklar ve küpeler çalışılmıştır. Söz konusu eserler müzeye satın alma ve müsadere olarak kazandırılmıştır. Bu calışmanın amacı Diyarbakır Müzesi’nden bir grup takıyı değerlendirmek, Yakındoğu'daki benzerlerinden yola çıkarak tarihleme yapmak ve bu konuda yapılacak araştırmalara katkı sağlamaktır. Takıların her biri kendi içinde tipolojik ve stil olarak farklılık göstermektedir. Söz konusu takıların üretiminde çoğunlukla bronz nadiren altın, altın kaplama, gümüşs ve demir madeni kullanılmıştır. Takılardan gözlü süs iğneleri cire pérdue tekniği; fibulalar ve bilezikler döküm tekniği; küpeler ve metal boyun halkalar ise dövme tekniğinde üretilmiştir. Süslemeler ise linear yöntemiyle yapılmıștır. Süs iğneleri, fibulalar, bilezikler ve boyun halkalarında görülen süslemeler dönemin ustalarının kuyumculukta ulaştığı seviyeyi de göstermesi açısından önemlidir. Bu güne kadar bilinen takılarda olduğu gibi Diyarbakır Müzesi takıları da ölü armağanı, kişisel süs eşyası, kötülüklere karşı muska veya giyim kuşamda aksesuar olarak kullanılmış olmalıdır. Çalışmamızda incelenen Diyarbakır Müzesi koleksiyonuna ait 47 metal takı benzer örneklerinden yola çıkılarak Erken ve Orta Demir Çă̆’na tarihlendirilmişlerdir.

\begin{abstract}
In this article, we present a selection of previously unpublished metal jewellery (decorative pins, fibulae, bracelets, neck rings, and earrings) housed at Diyarbakur Museum, where they were acquired by requisition or purchase. The objective of this study is to evaluate these jewellery items with common characteristics as a group and to provide a chronological assessment based on comparative typological analysis in reference to ancient Near Eastern jewellery. This contribution furthers our knowledge about the archaeological record of the Upper Tigris basin in southeast Turkey, where Diyarbakur province is located. All categories of jewellery items examined in this study show typological variability in sub-types and exhibit stylistic diversity. The majority are made of bronze, while fewer are gold-plated or made of gold, silver or iron. Jewellery items vary in terms of manufacturing technology, as well: toggle pins are produced by lost wax (cire pérdue) technique; fibulae and bracelets are made by casting; and earrings and metal neck rings are made by hammering. Decorations are executed as incised patterns in linear style. Figurative adornments of toggle pins, fibulae, bracelets, and neck rings bear testimony to the high level of craftsmanship that their makers had achieved. These artefacts from Diyarbakır Museum, like most known jewellery in the archaeological record, must have been used as grave offerings or worn as items of personal adornment, amulets or accessories for garments. Based on comparative analysis, the 47 jewellery items in Diyarbakır Museum examined here are dated to the Early and Middle Iron Age.
\end{abstract}

The Upper Tigris basin in southeast Turkey is surrounded by Mount Karacadağ in the west, Mount Anduk in the east, southern foothills of the Southeast Taurus range in the north, and Mount Maz1 in the south. The modern province of Diyarbakir lies on the right bank of the 
Tigris River in this geographical basin. ${ }^{1}$ The earliest investigations in the region were carried out in 1861-63 and 1886 by J.G. Taylor, who discovered two Assyrian stelae known as "Kurkh Monoliths". ${ }^{2}$ Explorations in Diyarbakır region continued with the discovery of Birklinçay relief, inscriptions, and fortress by Belck in 1898-1900, and transcriptions of five inscriptions were published by Lehmann-Haupt. ${ }^{3}$ After a long break, surveys were conducted in the region by Kökten in 1946 and by Dönmez-Brice in 1947 under the auspices of Turkish Historical Society, and a joint project was led by Çambel and Braidwood in $1963 .{ }^{4}$ In the following decades, investigations at Eğil Fortress were undertaken by Wäfler in 1975, 5 and Birklin Cave inscription and reliefs were studied by Russell in $1984 .^{6}$ The year 1986 was a milestone for the history of archaeological research in the region. Systematic regional surveys were initiated by Sevin in 1986, followed by excavations at Üçtepe mound in 1988. During this period, intensive salvage work was carried out in the region, necessitated by the construction of Southeast Anatolia Project (GAP) hydroelectric dams. Many previously unknown archaeological sites were documented by systematic surveys in 1988 under Özdoğan's directorship. ${ }^{7}$ Concurrently, a team led by Algaze discovered about two-hundred-fifty mounds during systematic surveys in 1988-1990 along the Upper Tigris. ${ }^{8}$ Subsequently, "Salvage Project of the Archaeological Heritage of the Ilisu and Carchemish Dam Reservoirs" was initiated by METU-TAÇDAM in 1998. Many survey and excavation projects were undertaken by Turkish and international teams in the region, as part of this effort towards preserving cultural heritage.

Scientific archaeological explorations in the region over the last few decades have contributed immensely to our knowledge about the archaeological record of Diyarbakır province and the Upper Tigris basin. A substantial number of artefacts found during these surveys and excavations

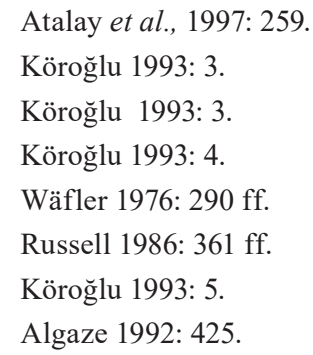

were registered to be housed at Diyarbakır Museum. Additionally, over the years the museum requisitioned and purchased many illicitly dug and unprovenanced artefacts, a selection of which is examined in this study. We hope that our examination of this group of previously unpublished jewellery from Diyarbakır Museum collections will be a timely contribution to the growing body of archaeological research in the Upper Tigris basin.

Jewellery from Diyarbakır Museum evaluated in this study consists of 12 toggle pins, 15 fibulae, 15 bracelets, 2 neck rings, and 3 earrings. First, a typological and stylistic evaluation of these artefacts in each main category is presented. Then, manufacturing techniques and functional aspects are evaluated. And finally, typological comparisons with ancient Near Eastern assemblages are discussed. Our examination of this group of jewellery from Diyarbakır Museum is an original assessment of these artefacts, the great majority of which have not been studied or published before.

Jewellery items examined in this study were acquired by Diyarbakır Museum through requisition or purchase from local individuals. In most part, archaeological jewellery items housed in the storage facilities of the museum have undergone proper cleaning and conservation procedures. The greater majority of the studied artefacts were found in the province of Diyarbakır, while fewer originate from Van province, and only one was brought from Gaziantep province. However, there is no available information about the archaeological contexts of these artefacts. For this reason, it is not possible to date these artefacts by context, nor is it possible to provide ranges of absolute dates. Nonetheless, using relative chronology methods, it is possible to date the examined jewellery to broad chronological periods based on a comparative analysis of typological, stylistic, and decorative elements.

\section{Typological Evaluation}

\section{A. Toggle Pins}

Toggle pins are decorative pins that feature a hole just below the head and are known to have variously shaped heads. ${ }^{9}$ The 12 decorative pins in Diyarbakır Museum collections all belong to the type known as 'toggle pin'. All

9 Çetin 2015: 3. 
are manufactured out of bronze. Based on the shape of their heads, these examples belong to four typological groups, namely poppy-shaped headed pins, bud-shaped headed pins, animal-figure headed pins, and pins with animal protomes. ${ }^{10}$

\section{A.1. Poppy-Shaped Headed Pins}

Four poppy-shaped headed pins with inventory numbers 2-6-96, 2-95-80, 13-32-76, and 20-875 in Diyarbakır Museum were examined in this study (Fig. 1/1-4). Cast of bronze, these pins vary in length between $6.6 \mathrm{~cm}$ and $9 \mathrm{~cm}$. The diameter of the poppy-shaped head is $0.9 \mathrm{~cm}$. In three of the four pins (excluding example in Fig. 1/1), multiple stigmas ${ }^{11}$ are marked on top of the poppy seed capsule. In the examples with multiple stigmas, grooves marking the stigmas are shallow, while the example with fewer stigmas features deeper grooves. The crowns of the heads are flattened, and the 'torus' (bulbous head) is formed as a compressed sphere. There are two circular rings just under the torus. The stems of the pins are wider around the hole and some have blunt, others pointed tips. The shape of the tip could not be determined in one of the examples, since it is broken at midsection (Fig. 1/1).

\section{A.2. Bud-Shaped Headed Pins}

Two of the toggle pins housed at Diyarbakir Museum (Inv. No. 3-6-87 and 21-7-75) feature bud-shaped heads (Fig. 2/1-2). They are both made of bronze. The pin inventoried as 21-775 is $8.2 \mathrm{~cm}$ long. Its head features one central bud on top and two pairs of buds on each side. There are two more groups of multiple buds placed approximately $1 \mathrm{~cm}$ below the buds on the crown. The hole of the toggle pin is shaped as a semi-circle (Fig. 2/1). The pin inventoried as 3-6-87 is $9.1 \mathrm{~cm}$ long. As opposed to the previous example, the crown of this pin features

10 In 1989, R. Yildirim conducted a study of Urartian Period decorative pins from various museums, including Diyarbakır Museum. While conducting our study on Iron Age jewellery at Diyarbakır Museum, we also re-examined the Urartian pins previously studied by R. Yildırım. Decorative pins reported in this study include pins studied by Y1ldırım, as well as other pins registered in the museum inventory.

11 Stigma is the botanical term used for the disc-shaped leaflets located on top of the poppy seed capsule, from which the flower emerges (Yıldırım 1989: 58). four buds. The buds are placed at the termination of upward extrusions from the torus. Torus has the form of a compressed sphere. The hole is circular (Fig. 2/2). The stem of the pin tapers toward the pointed tip in both examples.

\section{A.3. Animal-Figure Headed Pins}

Three animal-figure headed pins were examined in Diyarbakir Museum collections. Two of these pins (Inv. No. 5-9-80 and 10-21-97) feature lion figures (Fig. 3/1-2), while the third example (Inv. No. 21-6-75) features a mountain goat (Fig. 3/3). Pin 10-21-97 is made of silver, while the other two are made of bronze. Of the two lion-figure headed pins, pin 5-90-80 is 6.3 $\mathrm{cm}$ long, while pin $10-21-97$ is $5.7 \mathrm{~cm}$ long. The stylised lion figures are located at the crown of the head. The lions are depicted standing on four legs on a disc. The only detail marked on the figures is the mane on the neck. The tail is parallel to the legs. The torus is placed just below the disc that is supporting the lions, and two stacked rings are present just below the torus. The holes are shaped as a semi-circle. Pin 5-9-80 is broken and the lower part of the stem is missing. Pin 21-6-75, instead, features a mountain goat standing on four legs on top of a disc (Fig. 3/3). The tail is short; the eye is prominently marked; and horns are turned backwards. There is a torus just under the disc that supports the goat, and a single ring is placed below the torus. Pin 21-6-75 is $7.6 \mathrm{~cm}$ long.

\section{A.4. Pins with Animal Protome}

'Protome' is a descriptive term used for the depictions of the frontal part (i.e. head, neck, front legs, and upper body) of animals or mythological creatures. ${ }^{12}$ Three examples of protome headed pins were examined in Diyarbakır Archaeology Museum collections. All three are made of bronze. Pin 4-3-77 is $8.2 \mathrm{~cm}$ long and features protomes of three birds (eagles?) (Fig. 4/1). Figures are placed with their backs against one another. The beaks are depicted very prominently. Just below the protome figures is a torus with two stacked rings below it. Pin 13-23-77 features two cock/hen protomes (Fig. 4/2). This pin is $6.1 \mathrm{~cm}$ long. Features such as the crest, beak, wings, and eyes are all clearly executed. Just below the protomes

12 Yıldırım 1989: 27. 
is a disc, and under the disc, a torus and two stacked rings. Pin $20-7-75$ is $8.2 \mathrm{~cm}$ long and features three griffon protomes (Fig. 4/3). The griffon figures, albeit very stylised, have very prominent beaks. The disc below the protomes is shaped as a square with rounded corners, and two stacked rings are placed under the disc. All pins in this group are intact and have circular holes.

\section{B. Fibulae}

A total of 15 fibulae in Diyarbakir Museum collections were examined in this study. Based on the shape of their bodies, these fibulae can be grouped in four main categories, namely triangular, semi-circular, swollen-arch, and horseshoe-shaped fibulae. ${ }^{13}$

\section{B.1. Triangular Fibulae}

Only one of the fibulae in Diyarbakır Museum collections is a triangular fibula (Inv. No. 2-984 ), which is made of bronze and measures 1.8 $\mathrm{cm}$ in height (Fig. 5/1). The wire that serves as the pin of the fibula is attached to the body by coiling. The catch-plate is placed above the coil to fasten the wire. The catch-plate in this example is shaped as a rectangular plaque that is bent over the coiled joint. The arch of the fibula is decorated with a finely incised diamond pattern (Fig. 5/1).

\section{B.2. Semi-Circular Fibulae}

Eight semi-circular fibulae in Diyarbakır Museum collections (Inv. No. 2-16-93, 2-262-08, $3-9-85,3-10-85,3-12-85,12-2-84,11-46-75$ and 21-17-75) were examined in this study (Fig. 5/29). While the majority are made of bronze, one (3-12-85) is made of iron. They vary between 1.9 $\mathrm{cm}-9 \mathrm{~cm}$ in height. The arches are decorated with symmetrically arranged knobs ('torus') and round flanges. Knobs and flanges appear both alone and in various combinations. The wire that constitutes the pin of the fibula is joined to the body by coiling. In some examples, the pin is broken, but the coiling at the joint is still visible. The catch-plate, which is the component that prevents

13 In 2006, O. San examined a group of fibulae from Diyarbakır Museum. The fibulae discussed in the present study have different inventory numbers than the fibulae studied by O. San. the pin from sliding, is located above this coiled joint. Generally, the catch-plate is rectangular and bent. However, the catch-plate is shaped as a hand in two of the examples (Fig. 5/3, 5/6). In one example, all the fingers are articulated in detail including the thumb (Fig. 5/6), while the thumb is omitted in the latter (Fig. 5/3).

\section{B.3. Swollen-Arch Fibulae}

Five fibulae of this type (Inv. No. 3-5-84, 12-1-84, 12-6-75, 16-25-83, and 21-16-75) in Diyarbakır Museum collections were examined in this study (Fig. 6/1-5). All are made of bronze. They vary between $2.1 \mathrm{~cm}-3.7 \mathrm{~cm}$ in height. The arches of the fibulae are decorated with symmetrically arranged flanges, varying in number between one to three. In two intact fibulae, the pin joins the body by coiling. In the remaining three, the pin is broken and missing but the joint shows evidence of coiling. As is the case in semi-circular fibulae, the catch-plate is placed above the coiling. The catch-plate is rectangular and bent. The majority of fibulae in this group are undecorated, while in one example (Fig. 6/1), the 'swollen' part of the arch is decorated with diamond motifs in linear style.

\section{B.4. Horseshoe-Shaped Fibulae}

Only one horseshoe-shaped fibula in Diyarbakır Museum collections (Inv. No. 3-7-84) was examined in this study (Fig. 6/6). This fibula is made of bronze and measures $4.1 \mathrm{~cm}$ in height. Two sets of three round flanges are placed symmetrically on the arms, close to the terminations. Because the pin is broken and missing, it is not possible to know whether or not the pin was attached to the body by coiling. The catch-plate is formed as a schematised hand with a clearly articulated thumb. The body is decorated with a crudely executed diamond pattern (Fig. 6/6).

\section{Bracelets}

A total of 15 bracelets in Diyarbakır Museum collections were examined in this study. All are made of bronze. Based on the characteristics of their terminations, bracelets can be grouped under two main categories: open-ended bracelets and bracelets with overlapping ends.

\section{C.1. Open-Ended Bracelets}

A total of eight open-ended bracelets (Inv. No. 
$1-4-78,13-3-76,13-5-77,13-27-77,13-28-77,14-$ $3-76,18-21-82$, and 22-5-84) were evaluated in this study (Fig. 7/1-8). All are made of bronze. Diameter varies between $6.1 \mathrm{~cm}-7.8 \mathrm{~cm}$. Terminations are formed as snakeheads in all examples, except for two (Fig. 7/3, 7), in which they are formed as dragonheads. Albeit stylised, the heads are prominent. Eyes and nostrils of snake and dragon heads are executed as indentations. Two of the bracelets also bear incised decorations. In one example, the body is decorated with round incisions just below the head at both ends (Fig. 7/3,6), while the other bracelet has deep grooves across the body (Fig. 7/7).

\section{C.2. Bracelets with Overlapping Ends}

Seven bracelets of this type (Inv. No. 1-12-78, 1-13-78, 1-34-93, 2-2-82, 4-20-75, 4-26-75, and 46-1-08) in Diyarbakır Museum collections were examined (Fig. 8/1-7). All are made of bronze. Diameters vary between $6.3 \mathrm{~cm}-8.7 \mathrm{~cm}$. Five of the bracelets have dragonheads at terminations, while the remaining two feature snakeheads (Fig. $8 / 1,6-7)$. Figures are prominently executed with indentations for eyes and nostrils.

\section{Neck Rings}

Two neck rings in Diyarbakır Museum collections were examined. Based on the characteristics of the terminations, both examples fall under the main category of open-ended neck rings.

\section{D.1.Open-Ended Neck Rings}

The two neck rings in Diyarbakır Museum are inventoried as 9-32-97 and 11-1-97. One is made of silver (Fig. 9/1), the other bronze (Fig. 9/2). Neck ring 9-32-97 measures 13.4 in diameter, while neck ring 11-1-97 has a diameter of 19.9 $\mathrm{cm}$. Terminations are decorated. Both ends of neck ring 9-32-97 are decorated with diamond motifs in linear style (Fig. 9/1). In the latter, neck ring 11-1-97, both terminations are shaped as dragonheads (Fig. 9/2).

\section{E. Earrings}

Three earrings in Diyarbakır Museum collections were examined in this study (Fig. 10/1-3). Based on their form, all three examples belong to the main category of loop-shaped earrings.

\section{E.1. Loop-Shaped Earrings}

One of the three earrings (21-2-84) is made of bronze and plated with gold, while the other two (21-3-84 and 15-35-75) are made of gold. Earrings 21-2-84 and 21-3-84 have a diameter of $1.8 \mathrm{~cm}$, while earring $15-35-75$ measures $2.4 \mathrm{~cm}$ in diameter. The loops feature a small hole at each termination, which constitute two components that latch onto each other. In fact, the latch is preserved in earring 15-35-75, while this section is broken and missing in earrings 21-2-84 and 21-384 (Fig. 10/1-3).

\section{Manufacturing Techniques}

Within the framework of this study, 47 jewellery items in Diyarbakır Museum collections were examined. The majority are made of bronze. Items manufactured out of other metals include one silver toggle pin, one silver neck ring, two iron fibulae, one gold-plated earing, and two golden earrings. Since bronze (an alloy consisting of copper and tin) is resistant to the impact of natural elements, in general bronze is well-preserved in the archaeological record and thus, an abundance of bronze artefacts has been unearthed by excavations at ancient sites. Moreover, because bronze is relatively easy to smelt, form, and decorate, it was also a widely preferred material by metalsmiths in ancient periods. ${ }^{14}$ The relative abundance of bronze vis-à-vis other metals in the studied collection and in the repertoire of the broader ancient Near East may be explained in light of these factors.

Jewellery items examined here vary in manufacturing technique. Toggle pins were manufactured by lost wax (cire pérdue) technique (Fig. 1-4). After casting was complete and wax was removed, decorative features of the poppy crowns, animal figures, and animal protomes adorning the head were retouched by a pointed burin. ${ }^{15}$ The buds on the bud-shaped headed pins, on the other hand, were formed by granulation (Fig. 2/1-2). Fibulae (Fig. 5-6) and bracelets (Fig. 7-8) were produced by casting, while earrings and neck rings were formed by hammering. Two of the three earrings in Diyarbakır Museum collections were formed as loops with

14 Çilingiroğlu 1997: 108.

15 Belli 2010: 178. 
a hollow core, which was filled with clay so as to prevent the gold sheet from being bent or pressed (Fig. 10/1-2). This technique is known from loop-earrings found at Urartian sites. ${ }^{16}$ Fine decorative elements in toggle pins, fibulae, bracelets, and neck rings, which could not be executed in the moulds, were engraved on the surface after casting. These incised linear decorations are rather shallow and were probably made by burins with sturdy tips.

\section{Functional Analysis}

"In ancient periods before settled life, the earliest jewellery items were used by humans as amulets for ensuring successful hunts or for protection from malevolent forces. During this period, besides their religious and apotropaic function, jewellery items must have also been used as objects of personal adornment with the intention of impressing others". ${ }^{17}$ Subsequently, with the rise of inequality between social classes and technological advancements, objects of personal adornment acquired additional meanings and functions.

Archaeological record of the ancient Near East bears testimony to the wide jewellery repertoire that was in use across the periods. In light of findings from excavations, we can surmise that jewellery items were used by members of various social classes ranging from high-level administrators to the public. Ancient Near Eastern jewellery repertoire appears to be diverse not only typologically and stylistically, but also functionally. In fact, artistic depictions on various media and jewellery items found in graves provide a wealth of information about the use and function of various jewellery items. Depictions and statuettes of humans (male-female), gods/goddesses, and mythological creatures often bear details for earrings, belts, fibulae, medallions, pectorals, bracelets, and armlets, while decorative pins and neck rings are less frequently shown. ${ }^{18}$ Jewellery items detailed out in these depictions seem to be those that serve to mark distinction in social status and display wealth through personal

16 Belli 2010: 156

17 Meb 2006: 3-4.

18 Stronach 1959: 204; Muscarella 1967: Pl. IV/Fig. 3; Pl. VI/Fig. 7, Pl. VII/Fig. 8; Bonatz 2014: 40, Fig. 3.1. adornment. 19

Apart from representations in art, excavated mortuary assemblages also provide invaluable information. Earrings, rings, decorative pins, fibulae, belts, necklaces, neck rings, bracelets, and armlets have been found in graves. Studies on these mortuary assemblages indicate that jewellery items were placed in graves as funerary offerings, items of personal adornment, and/or as apotropaic amulets. ${ }^{20}$

Jewellery items appear as important components of clothing during ancient times. Besides being decorative accessories for garments, these objects may have served various other functions. For instance, fibulae were used for fastening garments in various ways, as can be seen in monumental scale reliefs. Fibulae are shown joining the ends of a cloak in Khorsabad and Bor orthostats; fibulae are fastened over the shoulder in Persepolis Apadana and Zincirli orthostats; and they are placed over the belt in Persepolis Apadana and Maraş orthostats. ${ }^{21}$ Toggle pins also appear in artistic depictions in various ways. A decorative toggle pin appears used as a pendentive on the chest of the Urartian Period female statuette known as Derebey figurine, ${ }^{22}$ while a toggle pin is shown adorning the head of the queen on a 11th Dynasty sarcophagus from Egypt. ${ }^{23}$ An illustrative archaeological parallel is known from Van/Kalecik Urartian necropolis, where an in situ poppy-shaped headed pin was discovered just next to the skull of a female skeleton in Grave Ka.3. ${ }^{24}$ Based on these examples, we may conclude that, while toggle pins did serve the functional purpose of fastening garments, they could also be used for purely aesthetic purposes. ${ }^{25}$ Larger fibulae and decorative pins would have been used for fastening garments made of coarse textiles, and smaller ones for

19 Çavuşoğlu 2015: 232.

20 Muscarella 1967: 86; Yıldırım 1989: 17; Üngör 2015: 153; Çavuşoğlu 2015; Köse et al., 2018: 64.

21 Muscarella 1967: Pl. II/Fig. 1 (Khorsabad), Pl. III/Fig. 2 and Pl. IV/Fig. 3 (Persepolis Apadana); Pl. V/Fig. 6 (Bor Orthostat); PL. VI/Fig. 7 (Zincirli Orthostat); Pl. VIII/Fig. 8 (Maraş Orthostat).

22 Gökce 2013: 215, Fig. 4.

23 Lange 1968: P1. 83.

24 Çavuşoğlu 2015: 231.

25 Y1ldırım 1989: 14; San 2006: 37-38. 
finer textiles. Apart from being accessories for garments, decorative pins were also used as hair pins or for fastening head scarfs.

In ancient periods, jewellery items also played an important role in gift economy. For instance, historical records of the Neo-Assyrian Empire relate that military officials were rewarded with jewellery items for their successful deeds in expeditions. In a source that dates to the reign of one of the latest Assyrian kings, Ashur-etil-ilani (630-627 B.C. E.), the following passage is attested regarding this practice: "I planned to do them good: I clothed them with multi-coloured robes and bound their wrists with golden bracelets... fields, orchards, buildings and people I exempted from tax and gave to them". 26

The group of jewellery items in Diyarbakır Museum collections examined in this study were acquired by the Museum by requisition or purchase. Thus, we have no information about the provenance and the contexts of these finds. However, in light of evidence for comparable examples from ancient Near Eastern sites, we may conclude that the objects evaluated in this study were used as funerary offerings, items of personal adornment, amulets, and accessories for fastening garments.

\section{Typological and Chronological Comparisions with Ancient Near Eastern Assemblages}

To reiterate, the group of examined jewellery in Diyarbakir Museum collections consists of decorative pins, fibulae, bracelets, neck rings, and earrings. The decorative toggle pins belong to four typological groups: poppy-shaped headed, bud-shaped headed, animal-figure headed pins, and pins with animal protomes. Poppyshaped headed pins are frequently attested in excavated assemblages and artistic depictions in Anatolia and the Near East. Examples of this pin type in artistic depictions can be seen adorning the heads of goddess figurines found at Gazi in Crete, ${ }^{27}$ as well as the 11th Dynasty Egyptian sarcophagus relief scene, mentioned above, in which a poppy-headed shaped pin is

26 Radner 2011: 45.

27 Hood 1978: 108-109, Fig. 92. seen adorning the head of the queen.28 Among comparable examples of poppy-shaped headed pins from excavated contexts, close parallels were found at the city of Nippur (Kassite Period), in Luristan region, at Beştaşhani in the Caucasus, at Tell el Duveir (Lachish) in Southern Levant, from graves at Enkomi and Lapithos in Cyprus, at Boğazköy in Central Anatolia, and at Urartian settlement centres of Kayalıdere, Adilcevaz, and Giriktepe, as well as Urartian cemeteries of Van/Kalecik and Van/ Altıntepe. ${ }^{29}$ Among these examples, pins found at Beştaşhani in the Caucasus and pins from Urartian centres and cemeteries are the closest typological and stylistic parallels for poppyshaped headed pins from Diyarbakır Museum collections evaluated here (Fig. 1/1-4).

Bud-shaped headed pins constitute the second type of decorative pins evaluated in this study. Çetin states that bud-shaped headed pins found at Baklatepe Early Bronze Age I (3200-3700 B.C.E.) cemetery and at Alacahöyük Grave K (Early Bronze Age II) may be regarded as the predecessors of five-bud-shaped headed pins in Anatolia. ${ }^{30}$ Bud-shaped headed pins are also known from later Anatolian sites; e.g. one was found in Grave III (1200 B.C.E.) at Pulur mound, ${ }^{31}$ and several examples were found at the Hittite Period cemetery of Polatl (Gordion). ${ }^{32}$ In the Caucasus, bud-shaped headed pins are reported from a 8 th-7th c. B.C.E. grave at Treli and from the site of Tli Grap. ${ }^{33}$ In Luristan, two bud-shaped headed pins were found in the Early Iron Age level of Shurabah. ${ }^{34}$ However, apart from the globular form of individual buds that is a common element in examples cited above from Anatolia (Pulur and Gordion), the Caucasus, and Luristan, none

\footnotetext{
28 Lange 1968: Pl. 83.

29 Godard 1931: Pl. 33/139 (Luristan); Kuftın 1941:73, Fig. 80/5 (Beștaşhani); Jacopsthal 1956: 38 (Cyprus), 39 (Tell el Duveir); Burney 1966: Fig. 21/13 (Kayalıdere); Mccown et all., 1967: Fig. 152/3 (Nippur); Boehmer 1972: Pl. 277, 295 (Boğazköy); Öğün 1978: Pl. 31/Abb. 17 (Adilcevaz); Ayaz 2006: 64, 70 (Van/Altıntepe); Belli 2010: 339; Çavuşoğlu 2015: Fig. 7/3-6, 13 (Van/ Kalecik).

30 Çetin2015: 6.

31 Koşay- Vary 1964: 48, 45, Pl. CIX/a, d.

32 Mellink 1956: Pl. 17/j-1, Pl. 19/e-f.

33 Çetin2015: 7.

34 Overlaet 2005: Pl. 4/10-11.
} 
of these pins bear close similarity to the budshaped headed pins from Diyarbakır Museum. On the other hand, bud-shaped headed pin with Inv. No. 3-6-87 (Fig. 2/2) displays certain characteristics that are typical of toggle pins from Urartian cemeteries of Van/Altıntepe and Van/ Kalecik. ${ }^{35}$ The form of the torus and the ring below, as well as the broadening of the stem around the hole are common elements in these examples.

As for animal-figure headed pins, lion-headed pins are represented by one Early Iron Age example in Luristan, ${ }^{36}$ and one example from Hasanlu Period IVB (1050-800 B.C.E.) in Iran. ${ }^{37}$ Two lion-headed pins were found in Grave Ka.3 and Grave Ka.5 at the Urartian necropolis of Van/Kalecik. ${ }^{38}$ Examples of mountain goat headed pins, on the other hand, are known from Byblos and Megiddo in the Levant, and from sites in Luristan and the Caucasus. ${ }^{39}$ As is the case with bud-shaped headed pins, none of the animal-figure headed pins from Near Eastern contexts cited above bear close similarity to the animal-figure headed pins evaluated in this study (Fig.3/1-3). Animal-figure headed pins in Diyarbakır Museum, on the other hand, also display common characteristics of Urartian toggle pins, such as the torus, the rings, and the broadening of the stem around the hole. One formal parallel that may be drawn between the goat-headed pin with Inv. No. 21-6-75 (Fig. 3/3) and the examples from Megiddo, Byblos, and Luristan is the articulation of the empty space between the fore-legs and the hind-legs of the goat in all examples.

Pins with animal protomes, which constitute the fourth typological group of decorative pins evaluated here is not a widely attested type in the ancient Near East. Examples of cock/hen headed pins are known from Alishar in Central Anatolia and from various Urartian sites in Eastern Anatolia. ${ }^{40}$ Examples of pins with

35 Ayaz 2006: 64, 70; Çavuşoğlu 2015: Fig. 7/3-6, 13.

36 Godard 1931: Pl. XXXIII/136.

37 Ciferallı 2019: 154, Fig. 11.

38 Çavuşoğlu 2015: 231.

39 Jacopsthal 1956: 53, Fig. 241/a-b (Megiddo), Fig. 244 (Caucasus); Calmayer 1964: Pl. 63/127 (Luristan); Dayton 1978: Fig. 37 (Byblos).

40 Schaeffer 1948: Fig. 195/13 (Alişar); Yıldırım 1989: Figs. 13, 15-16 (Urartian); Belli 2010: 340 (Giriktepe). three eagle or griffon protomes are also attested at various sites of the Urartian Kingdom. ${ }^{41}$ Pins decorated with animal protomes evaluated here (Fig. 4/1-3) display typical characteristics of Urartian pins with respect to the form of the protomes, the torus, the double stacked rings, and the broadened stem around the hole.

Fibulae are attested in ancient Near Eastern assemblages from the 12th century B.C.E. onwards. In Mesopotamia and Iran, however, fibulae come into frequent use only in the 7 th century B.C.E. 42 Triangular fibulae have been found at Marlik in Grave 36 (late 8th c. B.C.E.) and in Neo-Assyrian Period graves at various sites; in Room MM of the Neo-Assyrian Northwest Palace at Nimrud; at Hasanlu Period II and Tepe Nush-i Jan Period I (last quarter of the 8th c. B.C.E.) in Iran; and in the Terrace Building at Gordion in Western Anatolia. ${ }^{43}$ The triangular fibula (Inv. No. 2-9-84) from Diyarbakır Museum is typologically similar to most examples known from the broader Near East. However, among these parallels, the fibula found in Room MM of the Northwest Palace bears the closest similarities in typology and decoration to the triangular fibula evaluated here (Fig. 5/1).

Semi-circular fibulae are widely attested in the Levant and the broader Eastern Mediterranean, in Anatolia, Mesopotamia, Iran, and Luristan. ${ }^{4}$ In general, semi-circular fibulae evaluated here (Fig. 5/2-9) are typologically similar to examples known from the greater ancient Near East with respect to the form of the arch, torus and flange decorations on the body, shape of the pin and the catch-plate. In particular, the semi-circular fibula registered as 2-262-08 in Diyarbakır Museum (Fig. 5/2) displays common characteristics with fibulae found at Hazor

41 Yildırım 1989: 35, 37-38.

42 San 2006: 37.

43 Stronach 1959: Pl. L/6; (Neo-Assyrian, Northwest Palace); Muscarella 1967: Pl. XVIII/95 (Gordion); Muscarella 1984: 416, Fig. 2 (Marl1k); Muscarella 1988:46, Fig. 52 (Hasanlu), 209, Fig. 317 (Tepe Nush-i Jan); Pedde 2018: 353, Figs. 18.3, 18.4, 356, Figs. 18.5, 18.7, 18.8, 357, Fig. 18.9 (Neo-Assyrian).

44 Piotrovskii 1952: Fig. 18; Stronach 1959: 182, Fig. 1/6; Muscarella 1967: Pl. XIV/72e, 76, Pl. II-5-10; Öğün 1978: Pl. 31/Abb. 15; Muscarella 1988: 359, Figs. 481482; Pedde 2018: 353, Fig. 18.1, 18.2; Pedde 2000; Çavuşoğlu 2015: Fig. 7/33-34. 
(Area B, Level IV, 8th - late 7th c. B.C.E.), ${ }^{45}$ and at Hama (Level F, 1175/50-900 B.C.E.). ${ }^{46}$ Fibula 11-46-75 in Diyarbakır Museum (Fig. $5 / 3$ ) is similar to semi-circular fibulae from Urartian sites, ${ }^{47}$ while fibula 21-17-75 (Fig. 5/5) is similar to examples known from Al-Mina (8th c. B.C.E. ${ }^{48}$ and Luristan. ${ }^{49}$ Close parallels for fibula 3-10-85 (Fig. 5/7), on the other hand, are known from Lidar Höyük on the Upper Euphrates ${ }^{50}$ and Nippur,51 while an example from Deve Höyük (Upper Euphrates) bears close similarity to fibula 12-2-84 (Fig. 5/8). ${ }^{52}$

Swollen-arch fibulae are also widely attested in a broad geographical sphere. Swollen-arch fibulae have been found at Gordion in Western Anatolia; Urartian centres of Bastam and Toprakkale and the Urartian necropolis of Van/ Altıntepe; Nor-Aresh Grave 1 in Armenia, Hasanlu (Period III) in Iran, and various other sites in the Southern and Northern Caucasus. ${ }^{53}$ Among the swollen-arch fibulae from Diyarbakır Museum, fibula 16-25-83 (Fig. 6/2) and fibula 12-1-84 (Fig. 6/4) are similar to fibulae known from Urartian centres mentioned above. Fibula 21-16-75 (Fig. 6/3), on the other hand, bears similarities to the example known from Hasanlu Period III, while the diamond motif on the body of fibula 3-5-84 (Fig. 6/1) is parallel to the examples known from the Southern Caucasus cited above. The last fibula evaluated in this study is a horseshoe-shaped fibula (Inv. No. 3-7-84), which is a commonly attested form at Phrygian sites. Fibulae of this type have been found at Gordion during the excavations of Tumulus P, Tumulus MM, and Tumulus W. ${ }^{54}$ The horseshoe-shaped fibula

45 Pedde 2000: Taf. 24/343.

46 Pedde 2000: Taf. 2/20.

47 Ögün 1979: 185, Abb. 10.

48 Pedde 2000: Taf. 27/390.

49 Pedde2000: Taf. 28/395.

50 Pedde 2000: Taf. 7/234.

51 Pedde 2000: Taf. 7/225.

52 Pedde 2000: Taf. 32/461.

53 Barnett 1963: 195, Fig. 42 (Nor Aresh); Muscarella 1965: Pl. 58/Fig. 8/19, Fig. 6/2, 4, Pl. 57/Fig. 2 (Hasanlu); Muscarella 1967: Pl. V/23, 26, Pl. VIII/43, Pl. XVI/8889 (Gordion); Kroll 1979: 172, Abb. 11/3 (Bastam); Pedde 2000: Taf. 23/304 (Toprakkale); Ayaz 2006: 110114 (Van/Altıntepe).

54 Muscarella 1967: Pl. II/8, Pl. III/12-17; Pl. IV/18-21; Pl. V/25. from Diyarbakir Museum (Fig. 6/6) is typologically similar to the Phrygian examples. At the same time however, this fibula shows characteristics of Urartian fibulae with respect to the hand-shaped catch-plate and the decorative flanges. Additionally, the linear diamond pattern decorating the body of this fibula is characteristic of fibulae known from the Southern Caucasus, cited above.

Open-ended bracelets constitute an important group of jewellery across the periods in the Near East. Examples of open-ended bracelets are known in ancient Anatolia from Early Bronze Age I contexts at Baklatepe and Arslantepe, Hittite Period levels at Alacahöyük, and Iron Age level at Değirmentepe (Malatya). ${ }^{55} \mathrm{~A}$ common characteristic of these bracelets is that the terminations are shaped as bulbous nodules. Examples of open-ended bracelets with nodular terminations and bracelets with terminations shaped as animal heads (e.g. dragon, snake) are known from Urartian centres of Armavir-Blur, Bastam, and Karmir-Blur, as well as Urartian cemeteries at Van/Altıntepe, Van/Kalecik, Iğdır, and Patnos/Dedeli. ${ }^{56}$ An open-ended bracelet with snake-headed terminations is also known from the Late Hittite Period levels of Carchemish ${ }^{57}$. A variety of open-ended bracelets are known from sites in Northwest Iran, including a snake-headed bracelet from Hasanlu Period IV, 58 open-ended bracelets with groovedecorated terminations from Dinkhatepe ${ }^{59}$ and Marlık, ${ }^{60}$ and an example with ram-headed terminations from Kani Koter. ${ }^{61}$ Examples of open-ended bracelets from Luristan include those with terminations shaped as the head of

55 Esin-Harmankaya 1985: Pl. VIII/1 (Malatya-Değirmentepe); Frangipane 1998: 307, Fig. 9 (Arslantepe); Keskin 2009: Pl. 44/2 (Baklatepe); Çetin 2015: 11 (Alacahöyük).

56 Barnett 1963: 178, Fig. 32/7, 9-10 (Iğdır); Piotrovski 1970: Fig. 79 (Karmir-Blur); Martırosjan 1974: 137, Pl. Fig. 85 (Armavir-Blur); Öğün 1978: Pl. 31/Abb. 14 (Patnos/Dedeli); Kroll 1979: 153, Abb. 1/21, 178, Abb. 16/9 (Bastam); Ayaz 2006: 20-21 (Van/Altıntepe); Çavuşoğlu 2015: 237, Fig. 5/1-12 (Van/Kalecik).

57 Marchetti 2012: 137.

58 Muscarella 1988: 34, Fig. 17-18, 36, Fig. 23.

59 Muscarella 1974: 45, Fig. 12/1038, Fig. 48/456, 368, 710.

60 Negahban 1996: 169, Pl. 82/355.

61 Amelırad and Azizi 2019: Fig. 11, Fig. 12/b. 
a pig, a duck, and a lion. ${ }^{62}$ Among these examples, the snake-headed bracelet from Hasanlu and various bracelets from Urartian sites are the closest parallels to the open-ended bracelets from Diyarbakır Museum (Fig. 7/1-8) with respect to general form and the animal-headed terminations.

As for bracelets with overlapping ends, they are widely attested at Anatolian sites: Arslantepe (Early Bronze I), Çorum-Resuloğlu (Early Bronze Age), Sarıkent (Early Bronze II), Bakla Tepe (Early Bronze II), İzmir-Ulucak (mid/late-2nd millennium B.C.E.), and the Hititte cemetery at Gordion. ${ }^{63}$ The terminations of bracelets found at these sites are simple and plain. Bracelets with overlapping ends shaped as dragon or snake heads are known from Urartian centres of Armavir-Blur and Toprakkale, as well as from Van/Altıntepe and Van/Kalecik Urartian cemeteries. ${ }^{64}$ In Northwest Iran, bracelets with snake-headed terminations are found at Hasanlu IV $^{65}$ and Dinkhatepe. ${ }^{66}$ Additionally, a bracelet with plain overlapping ends is reported from the Neo-Assyrian levels of Nippur. ${ }^{67}$ As is the case with open-ended bracelets, bracelets with overlapping ends evaluated here (Fig. 8/1-7) bear close typological similarities to bracelets with animal-headed terminations known from Hasanlu and Urartian Period sites.

Metal neck rings is not a widely attested jewellery type in the Near East. Neck rings are known from mortuary contexts in Anatolia, at Karataş-Semayük (Early Bronze II), Ahlatlıbel (Early Bronze Age), and İkiztepe (Early Bronze III). ${ }^{68}$ Neck rings are also known from Urartian centres of Murat Tepe, Giriktepe,

62 Muscarella 1988: 168, Figs. 265-266, 169, Figs. 268-269.

63 Mellink 1956: Pl. 20/A-B (Gordion Hittite Cemetery); Frangıpane 1998: 307, Fig. 9 (Arslantepe); Abay et al. 2000: 367, Fig. 7/D-E (İzmir-Ulucak); Fidan 2005: Pl. 100/Cat. No. 284 (Sarıkent); Yıldırım - İpek 2009: 34, Fig. 12 (Çorum-Resuloğlu); Keskin 2009: Pl. 16/343350 (Baklatepe)

64 Martirosjan 1974: 32, Fig. 16 (Armavir-Blur); Wartke 1990: Taf. Xx11/A (Toprakkale); Ayaz 2006: 21 (Van/ Altıntepe); Çavuşoğlu 2015: Fig. 5/2 (Van/Kalecik).

65 Muscarella 1988: 34, Fig. 19, 36, Fig. 24-25.

66 Muscarella 1974: 41, Fig. 6/453.

67 Mccown et al. 1967: Pl. 151/6.

68 Fidan 2005: 80. and Toprakkale. ${ }^{69}$ Additionally, neck rings are found at Dinkhatepe (1400-1200 B.C.E.) and Kani Koter (Iron Age) in Northwest Iran. ${ }^{70}$ However, none of these examples bear close similarity to neck ring 9-32-97 (Fig. 9/1) and neck ring 11-1-97 (Fig. 9/2) from Diyarbakir Museum. It may be pointed out, on the other hand, that the blunt and indented terminations of the neck ring in Fig. 9/1 are similar to the example from Giriktepe cited above. Dragon heads of the neck ring in Fig. 9/2 also bear stylistic and technical similarity to dragon heads on Urartian bracelets.

And finally, close parallels of loop-shaped earrings (Fig. 10), which constitute the last category of jewellery evaluated here, were found in Grave 3 at Yoncatepe (Early Iron Age). ${ }^{71}$ Similar examples of loop-shaped earrings can also be seen on display at Van Museum (7th c. B.C.E.), which are unprovenanced finds from illicit excavations at Urartian sites. ${ }^{72}$

\section{Conclusion}

In summary, the selection of jewellery from Diyarbakır Museum collections presented in this study consists of decorative toggle pins, fibulae, bracelets, neck rings, and earrings. These objects are predominantly made of bronze, while fewer examples are gold-plated or made of gold, silver or iron. Indeed, a great majority of artefacts found in excavations at Near Eastern settlements and cemeteries appears to be made of bronze. Being a malleable alloy, relatively easy to form, bronze may have been the material preferred by artisans, leading to its abundance in the archaeological record, as has been suggested before. ${ }^{73}$ This explanation may also be valid for the predominance of bronze in the studied collection.

Different categories of jewellery from Diyarbakır Museum examined in this study vary in manufacturing techniques. Decorative toggle pins are manufactured by lost wax

69 Wartke 1990: Taf. Xxxv11 (Toprakakle); Belli 2010: 298 (Giriktepe); Özdemir 2019: Fig. 3/5.

70 Muscarella 1988: 80, Fig. 141 (Dinkhatepe); Amelirad and Azizi 2019: 12, Fig. 14.

71 Belli 2010: 204.

72 Belli 2010: 226-230.

73 Çilingiroğlu 1997: 108. 
(cire pérdue) method; fibulae and bracelets are formed by casting; and earrings and neck rings are formed by hammering. Decorations are predominantly executed as linear incisions, and granulation is applied in a few examples. Extant evidence suggests that there were metalsmiths and jewellers among the many craft specialists and artisans in ancient Near Eastern societies. In fact, textual sources from Mesopotamia speak of "zadim" (jeweller) and "kudim/kuttimum" (goldsmith). ${ }^{74}$ The selection of jewellery examined here must have also been the work of specialised jewellers. The wide spectrum of manufacturing techniques observable in the evaluated collection suggests that technical specialisation and division of labour would have been a part of the production process.

Iconographic and mortuary evidence across the greater ancient Near East demonstrates that jewellery items were used widely by men, women, and children alike. However, perhaps more than age and gender, jewellery use most certainly marked and reflected distinctions in social status. In this regard, it may be suggested that cuneiform-inscribed jewellery and high quality jewellery items that display iconographic or stylistic complexity were used by royalty and the elite, while simple and plain jewellery types were used by lower social classes. As for the selection of jewellery from Diyarbakır Museum collections, because these objects were unearthed by illicit excavations, there is no information regarding their contexts. As such, it is not possible to infer whether they belonged to the elite or the lower social classes based on contextual interpretation. However, based on comparisons with excavated assemblages from Near Eastern sites, we suggest that the animalfigure headed toggle pins, gold and gold-plated earrings, and decorated fibulae in this collection belonged to individuals who were members of the social elite.

To reiterate, the selection of 47 jewellery items from Diyarbakır Museum collections examined here were acquired by requisition or purchase and as such, no contextual information is available for these artefacts. For this reason, as stated in the introduction, these finds can only be dated by relative chronology methods based

74 Mcintosh 2005: 258. on comparisons with analogous finds from secure archaeological contexts. Accordingly, poppy-shaped headed pins (Fig. 1/1-4) and pins with animal protomes (Fig. 4/1-3) are dated to the Middle Iron Age, while bud-shaped headed pins (Fig. 2/1-2) and animal-figure headed pins (Fig. 3/1-3) are dateable to the Early or Middle Iron Age. The fibulae evaluated here (Fig. 5-6) date to the 8th-7th centuries B.C.E.; the bracelets (Fig. 7-8) and neck rings (Fig. 9/1-2) belong to the Middle Iron Age, and finally the earrings (Fig. 10/1-3) are dateable to the Early or Middle Iron Age.

Some of the examples in the studied Diyarbakır Museum collection are decorated with lion, mountain goat, cock/hen, bird (eagle?), snake, dragon, and griffon figures and linear-style diamond motifs. Such figures and motifs are widely attested in Urartian art. In fact, it has been pointed out that besides their decorative function, such elements of Urartian iconography transformed these objects into apotropaic amulets, mystically charged items, and representations of might and power. ${ }^{75}$ Along parallel lines, we believe that the decorative elements of the jewellery items presented in this study also conveyed such significant messages.

\section{CATALOGUE}

\author{
A. Toggle Pins \\ Catalogue No.: 1 \\ Illustration No.: Fig. 1/1 \\ Identification: Poppy-shaped headed pin \\ Inventory No.: 2-6-96 \\ Dimensions: Length: $6.6 \mathrm{~cm}$ \\ Material: Bronze \\ Findspot: Unknown
}

Acquired by: Requisition from Şeyhmus Kaynar

Description: Poppy-shaped headed pin with flattened crown, simple globular torus, and two rings just below the torus; section around hole is broader than stem.

References for Comparable Finds: Kuftin 1941: 73, Fig. 80/5 (Beştaşhani In Caucasia); Burney 1966: Fig. 21/13 (Kayalidere); Ayaz 2006: 70 (Van/Altıntepe Necropolis); Çavuşoğlu 2015: Fig. 7/13 (Van/Kalecik Necropolis)

Catalogue No.: 2

Illustration No.: Fig. 1/2

75 Yıldırım 1989: 22; Çavuşoğlu 2011: 36. 
Identification: Poppy-shaped headed pin

Inventory No.: 2-95-80

Dimensions: Length: $9.3 \mathrm{~cm}$

Material: Bronze

Findspot: Unknown

Acquired by: Purchase from A. Kadir Dabaloğlu

Description: Poppy-shaped headed pin with flattened crown, simple globular torus, and two rings just below the torus; section around hole is broader than stem.

References for Comparable Finds: Öğ̈̈n 1978: Pl. 31/Abb. 17 (Adilcevaz); Ayaz 2006: 64 (Van/Altıntepe Necropolis); Belli 2010: 339; Çavuşoğlu 2015: Fig. 7/3-6 (Van/Kalecik Necropolis).

Catalogue No.: 3

Illustration No.: Fig. 1/3

Identification: Poppy-shaped headed pin

Inventory No.: 13-32-76

Dimensions: Length: $8.0 \mathrm{~cm}$

Material: Bronze

Findspot: Unknown

Acquired by: Purchase from Halil Dabakoğlu

Description: Poppy-shaped headed pin with flattened crown, simple globular torus, and two rings just below torus; section around hole is broader than stem.

References for Comparable Finds: Öğ̈̈n 1978: Pl. 31/Abb. 17 (Adilcevaz); Ayaz 2006: 64 (Van/Altıntepe Necropolis); Belli 2010: 339; Çavuşoğlu 2015: Fig. 7/3-6 (Van/Kalecik Necropolis).

Catalogue No.: 4

Illustration No.: Fig. 1/4

Identification: Poppy-shaped headed pin

Inventory No.: 20-8-75

Dimensions: Length: $6.6 \mathrm{~cm}$

Material: Bronze

Findspot: Unknown

Acquired by: Purchase

Description: Poppy-shaped headed pin with flattened crown, simple globular torus, and two rings just below the torus; section around hole is broader than stem.

References for Comparable Finds: Öğ̈̈n 1978: Pl. 31/Abb. 17 (Adilcevaz); Ayaz 2006: 64 (Van/Altıntepe Necropolis); Çavuşoğlu 2015: Fig. 7/3-6 (Van/Kalecik Necropolis).

\section{Catalogue No.: 5}

Illustration No.: Fig. 2/1

Identification: Bud-shaped headed pin

Inventory No.: 21-7-75

Dimensions: Length: $8.2 \mathrm{~cm}$

Material: Bronze
Findspot: Unknown

Acquired by: Purchase from Berdan Karagöz

Description: Bud-shaped headed pin with crown formed by one central bud on top and two pairs of globular buds on each side; one pair of symmetrical buds resembling grape bunches are placed on the stem $\mathrm{ca} .1 \mathrm{~cm}$ below head.

References for Comparable Finds: ---

Catalogue No.: 6

Illustration No.: Fig. 2/2

Identification: Bud-shaped headed pin

Inventory No.: 3-6-87

Dimensions: Length: $9.1 \mathrm{~cm}$

Material: Bronze

Findspot: Diyarbakır

Acquired by: Purchase from Abdullah Güner

Description: Bud-shaped headed pin with a four-bud crown, a compressed torus, and two rings below torus; section around hole much broader than stem.

References for Comparable Finds: ---

Catalogue No.: 7

Illustration No.: Fig. 3/1

Identification: Animal-figure headed pin

Inventory No.: 5-9-80

Dimensions: Length: $6.3 \mathrm{~cm}$

Material: Bronze

Findspot: Unknown

Acquired by: Purchase from Vural Yazıcıoğlu

Description: Lion-headed pin with simple globular torus and two stacked rings; section around hole much broader than stem.

References for Comparable Finds: ---

Catalogue No.: 8

Illustration No.: Fig. 3/2

Identification: Animal-figure headed pin

Inventory No.: 10-21-97

Dimensions: Length: $5.7 \mathrm{~cm}$

Material: Silver

Findspot: Unknown

Acquired by: Requisition

Description: Lion-headed pin with simple globular torus and two stacked rings; section around hole much broader than stem.

References for Comparable Finds: ---

Catalogue No.: 9

Illustration No.: Fig. 3/3

Identification: Animal-figure headed pin 
Inventory No.: 21-6-75

Dimensions: Length: $7.6 \mathrm{~cm}$

Material: Bronze

Findspot: Unknown

Acquired by: Purchase from Berdan Karagöz

Description: Mountain-goat-headed pin with simple globular torus and one ring; section around hole much broader than stem.

References for Comparable Finds: ---

Catalogue No.: 10

Illustration No.: Fig. 4/1

Identification: $P$ in with animal protome

Inventory No.: 4-3-77

Dimensions: Length: $8.2 \mathrm{~cm}$

Material: Bronze

Findspot: Unknown

Acquired by: Purchase from Berdan Karagöz

Description: Three eagle protomes on crown, simple globular torus and two stacked rings; section around hole much broader than stem.

References for Comparable Finds: Ylldırım 1989: 35 36, Figs. 17-19; Belli 2010: 340; Gögtaş and İit2019: 544, Fig. 12.

Catalogue No.: 11

Illustration No.: Fig. 4/2

Identification: $P$ in with animal protome

Inventory No.: 13-23-77

Dimensions: Length: $6.1 \mathrm{~cm}$

Material: Bronze

Findspot: Van

Acquired by: Purchase from Ísmail Binici

Description: Two cock/hen protomes on crown, simple globular torus and two stacked rings; section around hole much broader than stem.

References for Comparable Finds: YILDIRIM 1989: 35-36, Figs. 13-16.; GÖGTAŞ and IGITT 2019: 544, Fig. 11.

Catalogue No.: 12

Illustration No.: Fig. 4/2

Identification: Pin with animal protome

Inventory No.: 20-7-75

Dimensions: Length: $8.2 \mathrm{~cm}$

Material: Bronze

Findspot: Van

Acquired by: Purchase from İsmail Binici

Description: Three griffon protomes on crown, simple globular torus and two stacked rings; section around hole much broader than stem.
References for Comparable Finds: Barnett 1963: 195, Fig. 43; Yıldırım 1989: 35-36, Figs. 13-16.

B. Fibulae

Catalogue No.: 13

Illustration No.: Fig. 5/1

Identification: Triangular fibula

Inventory No.: 2-9-84

Dimensions: Height: $1.8 \mathrm{~cm}$

Material: Bronze

Findspot: Unknown

Acquired by: Purchase from Ahmet Özeser

Description: Triangular fibula, pin attached by coiling with rectangular catch-plate, body decorated with incised diamond motifs.

References for Comparable Finds: Stronach 1959: Pl. $L / 6$.

Catalogue No.: 14

Illustration No.: Fig. 5/2

Identification: Semi-circular fibula

Inventory No.: 2-262-08

Dimensions: Height: $9 \mathrm{~cm}$

Material: Bronze

Findspot: Unknown

Acquired by: Purchase from Hüsnü Ceylan

Description: Semi-circular fibula, pin attached by coiling with rectangular catch-plate.

References for Comparable Finds: Pedde 2000: Taf. 2/20, Taf. 24/343.

Catalogue No.: 15

Illustration No.: Fig. 5/3

Identification: Semi-circular fibula

Inventory No.: 11-46-75

Dimensions: Height: $2.2 \mathrm{~cm}$

Material: Bronze

Findspot: Van

Acquired by: Purchase from Ismail Binici

Description: Semi-circular fibula with catch-plate shaped as a hand; body and arms of arch decorated with round flanges.

References for Comparable Finds: Caner 1983: Taf. $44 / 655 a-B$.

Catalogue No.: 16

Illustration No.: Fig. 5/4

Identification: Semi-circular fibula

Inventory No.: 2-16-93

Dimensions: Height: $5.3 \mathrm{~cm}$

Material: Iron 
Findspot: Unknown

Acquired by: Purchase from Eyüp Diril

Description: Semi-circular fibula, pin attached by coiling with rectangular catch-plate; arms of the arch decorated with a knob and flanges.

References for Comparable Finds: ---

Catalogue No.: 17

Illustration No.: Fig. 5/5

Identification: Semi-circular fibula

Inventory No.: 21-17-75

Dimensions: Height: $3.0 \mathrm{~cm}$

Material: Bronze

Findspot: Unknown

Acquired by: Purchase from Berdan Karagöz

Description: Semi-circular fibula, pin attached by coiling with rectangular catch-plate; arms of the arch decorated with knobs and flanges.

References for Comparable Finds: Pedde 2000: Taf. 27/390, Taf. 28/395.

Catalogue No.: 18

Illustration No.: Fig. 5/6

Identification: Semi-circular fibula

Inventory No.: 3-9-85

Dimensions: Height: $2.0 \mathrm{~cm}$

Material: Bronze

Findspot: Diyarbakır

Acquired by: Purchase from Abdullah Güner

Description: Semi-circular fibula with broken pin; catch-plate shaped as a hand; arms of the arch decorated with round flanges.

References for Comparable Finds: ---

Catalogue No.: 19

Illustration No.: Fig. 5/7

Identification: Semi-circular fibula

Inventory No.: 3-10-85

Dimensions: Height: $1.9 \mathrm{~cm}$

Material: Bronze

Findspot: Diyarbakır

Acquired by: Purchase from Abdullah Güner

Description: Semi-circular fibula, pin attached by coiling with rectangular catch-plate; arms of the arch decorated with round flanges.

References for Comparable Finds: Plotrovsku 1952: Fig. 18; Pedde 2000: Taf. 7/225, 234.

Catalogue No.: 20

Illustration No.: Fig. 5/8

Identification: Semi-circular fibula
Inventory No.: 12-2-84

Dimensions: Height: $2.5 \mathrm{~cm}$

Material: Bronze

Findspot: Diyarbakır

Acquired by: Purchase from Abdullah Güner

Description: Semi-circular fibula with broken pin and rectangular catch-plate; arms of the arch decorated with a knob and flanges.

References for Comparable Finds: Pedde 2000: Taf. 32/461; Bilir 2019: 102, Type B.vil.

Catalogue No.: 21

Illustration No.: Fig. 5/9

Identification: Semi-circular fibula

Inventory No.: 3-12-85

Dimensions: Height: $3.5 \mathrm{~cm}$

Material: Iron

Findspot: Diyarbakır

Acquired by: Purchase from Abdullah Güner

Description: Semi-circular fibula with broken pin and rectangular catch-plate; arms of the arch decorated with a knob and flanges.

References for Comparable Finds: ---

Catalogue No.: 22

Illustration No.: Fig. 6/1

Identification: Swollen-arch fibula

Inventory No.: 3-5-84

Dimensions: Height: $3.7 \mathrm{~cm}$

Material: Bronze

Findspot: Diyarbakır

Acquired by: Purchase from Abdullah Güner

Description: Swollen-arch fibula with broken pin and rectangular catch-plate; body decorated with a diamond design in linear style.

References for Comparable Finds: Similar decoration in: Muscarella 1965: Pl. 58/Fig. 6/3a.

Catalogue No.: 23

Illustration No.: Fig. 6/2

Identification: Swollen-arch fibula

Inventory No.: 16-25-83

Dimensions: Height: $2.1 \mathrm{~cm}$

Material: Bronze

Findspot: Van

Acquired by: Purchase from İsmail Binici

Description: Swollen-arch fibula with broken pin, catch-plate shaped as a hand, body decorated with round flanges.

References for Comparable Finds: Pedde 2000: Taf. 23/317; Ayaz 2006: 113-114. 
Catalogue No.: 24

Illustration No.: Fig. 6/3

Identification: Swollen-arch fibula

Inventory No.: 21-16-75

Dimensions: Height: $2.5 \mathrm{~cm}$

Material: Bronze

Findspot: Unknown

Acquired by: Purchase from Berdan Karagöz

Description: Swollen-arch fibula, pin attached by coiling, catch-plate shaped as a hand, body decorated with round flanges.

References for Comparable Finds: Pedde 2000: Taf. 23/306; Özdemir 2019: Fig. 3/12.

Catalogue No.: 25

Illustration No.: Fig. 6/4

Identification: Swollen-arch fibula

Inventory No.: 12-1-84

Dimensions: Height: $2.3 \mathrm{~cm}$

Material: Bronze

Findspot: Diyarbakır

Acquired by: Purchase from Abdullah Güner

Description: Swollen-arch fibula with broken pin and rectangular catch-plate, body decorated with round flanges.

References for Comparable Finds: Kroll 1979: 172, Abb. 11/3; Pedde 2000: Taf. 23/304.

Catalogue No.: 26

Illustration No.: Fig. 6/5

Identification: Swollen-arch fibula

Inventory No.: 12-6-75

Dimensions: Height: $2.9 \mathrm{~cm}$

Material: Bronze

Findspot: G. Antep/Kilis

Acquired by: Purchase from Mustafa Dinçtürk

Description: Swollen-arch fibula, pin attached by coiling with rectangular catch-plate, body decorated with round flanges.

References for Comparable Finds: Pedde 2000: Taf. 23/314.

Catalogue No.: 27

Illustration No.: Fig. 6/6

Identification: Horseshoe-shaped fibula

Inventory No.: 3-7-84

Dimensions: Height: $4.1 \mathrm{~cm}$

Material: Bronze

Findspot: Diyarbakır

Acquired by: Purchase from Abdullah Güner
Description: Horseshoe-shaped fibula with broken pin, catch-plate shaped as a hand, arms decorated with round flanges, body decorated with diamond designs.

References for Comparable Finds: ---

C. Bracelets

Catalogue No.: 28

Illustration No.: Fig. 7/1

Identification: Open-ended bracelet

Inventory No.: 1-4-78

Dimensions: Diameter: $6.1 \mathrm{~cm}$

Material: Bronze

Findspot: Diyarbakır

Acquired by: Purchase from Halil Dabakoğlu

Description: Open-ended bracelet, terminations shaped as stylised snakeheads.

References for Comparable Finds: ---

Catalogue No.: 29

Illustration No.: Fig. 7/2

Identification: Open-ended bracelet

Inventory No.: 13-3-76

Dimensions: Diameter: $7.4 \mathrm{~cm}$

Material: Bronze

Findspot: Diyarbakır

Acquired by: Purchase from Halil Dabakoğlu

Description: Open-ended bracelet, terminations shaped as stylised snakeheads.

References for Comparable Finds: AYAZ 2006: 21.

Catalogue No.: 30

Illustration No.: Fig. 7/3

Identification: Open-ended bracelet

Inventory No.: 13-5-77

Dimensions: Diameter: $7.7 \mathrm{~cm}$

Material: Bronze

Findspot: $\operatorname{Van}$

Acquired by: Purchase from Ismail Binici

Description: Open-ended bracelet, terminations shaped as stylised dragonheads.

References for Comparable Finds: ---

Catalogue No.: 31

Illustration No.: Fig. 7/4

Identification: Open-ended bracelet

Inventory No.: 13-27-77

Dimensions: Diameter: $6.9 \mathrm{~cm}$

Material: Bronze

Findspot: Van

Acquired by: Purchase from Ismail Binici 
Description: Open-ended bracelet, terminations shaped as stylised snakeheads.

References for Comparable Finds: ÇAVUŞOĞLU 2015: 237, Fig. 5/11-12.

Catalogue No.: 32

Illustration No.: Fig. 7/5

Identification: Open-ended bracelet

Inventory No.: 13-28-77

Dimensions: Diameter: $7.8 \mathrm{~cm}$

Material: Bronze

Findspot: $\operatorname{Van}$

Acquired by: Purchase from Ismail Binici

Description: Open-ended bracelet, terminations shaped as stylised snakeheads.

References for Comparable Finds: Barnett 1963: 178, Fig. 32/9.

Catalogue No.: 33

Illustration No.: Fig. 7/6

Identification: Open-ended bracelet

Inventory No.: 14-3-76

Dimensions: Diameter: $7.0 \mathrm{~cm}$

Material: Bronze

Findspot: Diyarbakır

Acquired by: Purchase from Berdan Karagöz

Description: Open-ended bracelet, terminations shaped as stylised snakeheads.

References for Comparable Finds: Barnett 1963: Fig. 32/10; Öğün 1978: Pl. 31/Abb. 14; Kroll 1979: 178, Abb. 16/9; Muscarella 1988: 36, Fig. 23; Çavuşoğlu 2015: Fig. $5 / 2$.

Catalogue No.: 34

Illustration No.: Fig. 7/7

Identification: Open-ended bracelet

Inventory No.: 18-21-82

Dimensions: Diameter: $6.8 \mathrm{~cm}$

Material: Bronze

Findspot: Van

Acquired by: Purchase from Ísmail Binici

Description: Open-ended bracelet, terminations shaped as stylised dragonheads.

References for Comparable Finds: Barnett 1963: 178, Fig. 32/7; Martırosjan 1974: Pl. 85/1-2; Muscarella 1988: 34, Figs. 17-18; Ayaz 2006: 20; Gögtaş And Igit 2019: 541, Fig. 6.

Catalogue No.: 35

Illustration No.: Fig. 7/8

Identification: Open-ended bracelet

Inventory No.: 22-5-84
Dimensions: Diameter: $6.9 \mathrm{~cm}$

Material: Bronze

Findspot: $\operatorname{Van}$

Acquired by: Purchase from Ísmail Binici

Description: Open-ended bracelet, terminations shaped as stylised dragonheads.

References for Comparable Finds: Martırosjan 1974: Pl. 85/5; Kroll 1979: 153, Abb. 1/21.

Catalogue No.: 36

Illustration No.: Fig. $8 / 1$

Identification: Bracelet with overlapping ends

Inventory No.: 1-12-78

Dimensions: Diameter: $8.2 \mathrm{~cm}$

Material: Bronze

Findspot: Unknown

Acquired by: Purchase

Description: Bracelet with overlapping ends, terminations shaped as stylised snakeheads.

References for Comparable Finds: Martırosjan 1974. Fig. 16.

Catalogue No.: 37

Illustration No.: Fig. $8 / 2$

Identification: Bracelet with overlapping ends

Inventory No.: 1-13-78

Dimensions: Diameter: $6.9 \mathrm{~cm}$

Material: Bronze

Findspot: Diyarbakır

Acquired by: Purchase from Halil Dabakoğlu

Description: Bracelet with overlapping ends, terminations shaped as stylised dragonheads.

References for Comparable Finds: ---

Catalogue No.: 38

Illustration No.: Fig. 8/3

Identification: Bracelet with overlapping ends

Inventory No.: 1-34-93

Dimensions: Diameter: $7.9 \mathrm{~cm}$

Material: Bronze

Findspot: Unknown

Acquired by: Purchase

Description: Bracelet with overlapping ends, terminations shaped as stylised dragonheads.

References for Comparable Finds: Çavuşoğlu 2015: Fig. 5/2.

Catalogue No.: 39

Illustration No.: Fig. 8/4

Identification: Bracelet with overlapping ends 
Inventory No.: 2-2-82

Dimensions: Diameter: $8.7 \mathrm{~cm}$

Material: Bronze

Findspot: Unknown

Acquired by: Purchase

Description: Bracelet with overlapping ends, terminations shaped as stylised dragonheads.

References for Comparable Finds: Muscarella 1988: 36, Figs. 24-25.

Catalogue No.: 40

Illustration No.: Fig. 8/5

Identification: Bracelet with overlapping ends

Inventory No.: 4-20-75

Dimensions: Diameter: $8.4 \mathrm{~cm}$

Material: Bronze

Findspot: Van

Acquired by: Purchase from Ísmail Binici

Description: Bracelet with overlapping ends, terminations shaped as stylised dragonheads.

References for Comparable Finds: ---

Catalogue No.: 41

Illustration No.: Fig. $8 / 6$

Identification: Bracelet with overlapping ends

Inventory No.: 4-26-75

Dimensions: Diameter: $8.2 \mathrm{~cm}$

Material: Bronze

Findspot: Unknown

Acquired by: Purchase

Description: Bracelet with overlapping ends, terminations shaped as stylised snakeheads.

References for Comparable Finds: Wartke 1990: Taf. $X X I I / A$.

Catalogue No.: 42

Illustration No.: Fig. 8/7

Identification: Bracelet with overlapping ends

Inventory No.: 46-1-08

Dimensions: Diameter: $6.3 \mathrm{~cm}$

Material: Bronze

Findspot: Diyarbakır

Acquired by: Purchase from İettin Yayla

Description: Bracelet with overlapping ends, terminations shaped as stylised snakeheads.

References for Comparable Finds: Ayaz 2006: 21.

D. Neck Rings

Catalogue No.: 43

Illustration No.: Fig. 9/1
Identification: Open-ended neck ring

Inventory No.: 9-32-97

Dimensions: Diameter: $13.4 \mathrm{~cm}$

Material: Silver

Findspot: Unknown

Acquired by: Requisition

Description: Open-ended neck ring, terminations decorated with diamond motifs in linear style.

References for Comparable Finds: ---

Catalogue No.: 44

Illustration No.: Fig. 9/2

Identification: Open-ended neck ring

Inventory No.: 11-1-97

Dimensions: Diameter: $19.9 \mathrm{~cm}$

Material: Bronze

Findspot: Unknown

Acquired by: Unknown source

Description: Open-ended neck ring, terminations shaped as dragonheads.

References for Comparable Finds: Gögtaş and Igit 2019: 539, Fig. 1-2.

E. Earrings

Catalogue No.: 45

Illustration No.: Fig. 10/1

Identification: Loop-shaped earring

Inventory No.: 21-2-84

Dimensions: Diameter: $1.8 \mathrm{~cm}$

Material: Gold-plated bronze

Findspot: Van

Acquired by: Purchase from Ismail Binici

Description: Loop-shaped earring with one perforation on each end.

References for Comparable Finds: Belli 2010: 204, 226-230.

Catalogue No.: 46

Illustration No.: Fig. 10/2

Identification: Loop-shaped earring

Inventory No.: 21-3-84

Dimensions: Diameter: $1.8 \mathrm{~cm}$

Material: Gold

Findspot: Van

Acquired by: Purchase from Ismail Binici

Description: Loop-shaped earring with one perforation on each end.

References for Comparable Finds: Belli 2010: 204, 226-230. 
Catalogue No.: 47

Illustration No.: Fig. 10/3

Identification: Loop-shaped earring

Inventory No.: 15-35-75

Dimensions: Diameter: $2.4 \mathrm{~cm}$

Material: Gold

Findspot: Van

Acquired by: Purchase from Ísmail Binici

Description: Loop-shaped earring with one perforation on each end.

References for Comparable Finds: Belli 2010: 204, 226-230.

\section{Acknowledgments}

We thank the Directorate of Diyarbakir Archaeological Museum (Vehbi Yurt and Resmiye Timur) for granting us permission to study the objects evaluated in this investigation, and we thank Archaeologists Murat Aktay, Fulya Aydın, and Nesrin Şeker of Diyarbakır Museum for their assistance. And finally, we thank Dr. G. Bike Yazıcıoğlu for providing editorial assistance with English translation and proofreading.

\section{Bibliography}

ABAy vd. 2000: E. Abay, H. Sağlamtimur, T. Özkan, "Ulucak Höyük Kazılar1 1998”, KST 21/1, 359-370.

Algaze 1992: G. Algaze, "The Tigris-Euphrates Archaeological Reconnaissance Project, 1990", AST 9, 425-445.

Amelirad and Azizi 2019: S. Amelirad, E. Azizi, "Kani Koter, Iron Age Cemetery from Iranian Kurdistan", Iran 57, 1-20.

Atalay and Mortan 1997: İ. Atalay, K. Mortan, Türkiye Bölgesel Coğrafyası, İstanbul.

Ayaz 2006: Ayaz 2006, Van/Altıntepe Urartu Nekropolü Takılarl, (Unpublished Master's Thesis), Van Yüzüncü Y1l University, Van.

BarnetT 1963: R. D. Barnett, "The Urartian Cemetery at Igdry", AnSt 13, 153-198.

Belli 2010: O. Belli, Urartu Takılarl, İstanbul.

Bíir 2019: A. Bilir, "Bronze Fibulae of the Bolu Museum", Cedrus 7, 77-105.

Boehmer 1972: R. M. Boehmer, Die Kleinfunde von Boğazköy, Berlin.

BonAtz 2014: D. Bonatz, "katumuwa's Banquet Scene”, In: V. R. Hermann, J. D. Schloen (Eds.) In Remembrance of Me Feasting with the Dead in the Ancient Middle East, Chicago, 39-44.
Burney 1966: C. A. Burney, "A First Season of Excavations at the Urartian Citadel of Kayalidere", AnSt 16, 55-111.

Calmayer 1964: P. Calmayer, Altiranische Bronzen der Sammlung Bröckelschen, Berlin.

Caner 1983: E. Caner, Fibeln in Anatolien I, Prähistorische Bronzefunde XIV, 8, München.

Cifarelli 2019: M. Cifarelli, "Hasanlu, the Southern Caucasus and Early Urartu”, In: Pavel S. Avetisyan, Roberto Dan and Yervand H. Grekyan (Eds.), Over the Mountains and Far Away: Studies in Near Eastern history and archaeology presented to Mirjo Salvini on the occasion of his 80th birthday, 144-156.

ÇAvUşoĞLU 2015: R. Çavuşoğlu, "Van Kalecik Nekropolünden Urartu Takıları", In: M. Ișıklı, B. Can (Eds.) Uluslararası Doğu Anadolu Güney Kafkasya Kültürleri Sempozyumu Bildiriler II, 229-242.

Çetin 2015: C. Çetin, “Isparta Müzesi'nden Bir Grup Takı", Cedrus III, 1-30.

ÇiLingíRoĞLU 1997: A. Çilingiroğlu, Urartu Krallı̆̆ Tarihi ve Sanatı, İzmir.

Dayton 1978: J. Dayton, Minerals Metals Glazing \& Man, London.

Esin and Harmankaya 1985: U. Esin, S. Harmankaya, "1984 Değirmentepe (Malatya) Kurtarma Kazısı", KST 7, 53-86.

FidAn 2005: M: E. FIDAN, İç Batı Anadolu Orta Tunç

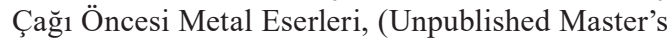
Thesis), Istanbul University, İstanbul.

FrangiPANE 1998: M. Frangipane, "Arslantepe 1996: The Finding of an E.B.I (Royal Tomb)", KST 19/1, 291-310.

Godard 1931: E. Godard, Les Bronzes du Luristan, Ars Asiatica 17, Paris.

GöKCE 2013: B. Gökce, "Urartular'da İnsan Biçimli Metal Heykelcikler", In: Oğuz Tekin, Mustafa H. Sayar ve Erkan Konyar (Eds.), Tarhan Armăganı/M. Taner Tarhan'a Sunulan Makaleler/Essays in Honour of M. Taner Tarhan, 211-217.

GöGtaş and İGít 2019: N. Gögtaş, İ. İgit, "Ahlat Müzesi'nde Bulunan Urartu Dönemi Madeni Takılar, Bingöl Üniversitesi Sosyal Bilimler Enstitüsü Dergisi 9.17, 535-552.

Hood 1978: S. Hood, The Arts in Prehistoric Greece, Yale University Press.

JACOPSTHAL 1956: P. Jacopsthal, Greek Pins and Their Connexions with Europe and Asia, Oxford.

Keskin 2009: İ. Keskin, İzmir Bölgesi Maden İşçiliği: Başlangıcından M.Ö. III. Binyll Sonuna Kadar Madeni Eser Üretimi ve Ticareti, (Unpublished PhD Thesis), Ankara University, Ankara. 
KoŞAY and VARY 1964: H. Z. Koşay, H. Vary, Pulur Kazısı, 1960 Mevsimi Çalışmaları Raporu, Ankara.

KöroĞLU 1993: K. Köroğlu, Yeni Kazı ve Yüzey Bulguları Işı̆̆ııda Diyarbakır/Üçtepe ve Çevresinin Yeni Assur Dönemi Tarihi Coğrafyası, (Unpublished Master's Thesis), İstanbul University, İstanbul.

KöSE and Girgin 2019: O. E. Köse, S. Girginer, "Erzurum Arkeoloji Müzesi'nde Bulunan Urartu Dönemi'ne Ait Madeni Bilezikler ve Pazıbentler", Arkeoloji ve Sanat 157, 63-82.

Kroll 1979: S. Kroll, "Die Kleinfunde", In: W. Kleiss (Ed.), Bastam I Ausgrabungen In Den Urartäischen Anlagen 1972-1975, 151-170, Berlin.

Kuftin 1941: B. A. Kuftin, Archaeological Excavations in Trialeti I, Tiflis.

Lange 1968: K. Lange, Aegypt Architecture, Sculpture, Painting in Three Thousand Years, London.

Marchetti 2012: N. Marchetti, "Karkemish on the Euphrates: Excavating a City's History", Near Eastern Archaeology 75.3, 132-146.

Martirosjan 1974: A. A. Martirosjan, Argistichinili, Jerewan.

Mellink 1956: M. J. Mellink, A Hittite Cemetry at Gordion, Philadelphia.

McCown et.al. 1967: D. E. McCown, R. J. Haines, D. P. Hansen, Nippur I, Chicago.

Mcintosh 2005: J. R. Mcintosh, Mesopotamia New Perspectives, Santa Barbara.

Milli EĞitim BAKanlıĞı 2006: Kuyumculuk Teknolojisi Takının Gelişimi, Ankara.

Muscarella 1965: O. W. Muscarella, "A Fibula from Hasanlu", AJA 69, 233-240.

Muscarella 1967: O. W. Muscarella, "Fibulae Represented on Sculpture", JNES 26.2, 82-86.

Muscarella 1974: O. W. Muscarella, "The Iron Age at Dinkha Tepe, Iran", Metropolitan Museum Journal 9, 35-90.

Muscarella 1984: O. W. Muscarella, "Fibulae and Chronology, Marlik and Assur", Journal of Field Archaeology 11/4, 413-419.

Muscarella 1988: O. W. Muscarella, Bronze and Iron Ancient Near Eastern Artifacts in the Metropolitan Museum of Art, New York.

Negahban 1996: E. O. Negahban, Marlik: The Complete Excavation Report, Philadelphia.

Overlaet 2005: B. Overlaet, "The Chronology of the Iron Age in the Pusht-1 Kuh, Luristan", Iranica Antiqua 40, 1-33.

ÖĞÜN 1978: B. Öğün, "Die Urartäischen Gräber in der Gegend von Adilcevaz und Patnos", Reprinted from the Proceedings of the Xth International Congress of Classical Archaeology, 61-67.
Özdemir 2019: A. Özdemir, "Murat Tepe'de Ele Geçen Urartu Dönemi Metal Eserleri”, Bingöl Üniversitesi Sosyal Bilimler Enstitüsü Dergisi 9/18, 731-749.

Pedde 2018: F. Pedde, "Fibulae in Neo-Assyrian Burials", In: E. Simpson (Ed.), The Adventure of the Illustrious Scholar Papers Presented to Oscar White Muscarella, Brill.

PedDe 2000: F. Pedde, Vorderasiatische Fibeln Von der Levante bis Iran, Germany.

Piotrovski 1952: B. B. Piotrovskii, Karmir-Blur II, Rezul'taty rakopok 1949-1950, Jerewan.

Piotrovski 1970: B. B. Piotrovskii, Karmir-Blur, Al'bom, Leningrad.

RADNER 2011: K. Radner, "Fame and Prizes: Competition and War in the Neo-Assyrian Empire", In: N. Fisher (Ed.) Competition in the Ancient World, 37-59.

Russell 1986: H. F. Russell, "Assyrian Monuments at the Tigris Tunnel", AST 3, 361-363.

SAN 2006: O. San, "Diyarbakır Müzesinde Yer Alan Urartu Tunç Fibulaları", Olba XIII, 35-54.

SchaEfFEr 1948: C. F. A. Schaeffer, Stratigraphie Compraée et Chronologie de l'Asie Occidentale, Oxford.

Stronach 1959: D. B. Stronach, "The Development of the Fibulae in the Near East", Iraq XXI, 180-206.

ÜNGÖR 2015: İ. Üngör, “Erzincan Müzesi’nde Bulunan Urartu Dönemine Ait Bir Grup Tunç Bilezikler ve Küpeler", Trakya Üniversitesi Edebiyat Fakültesi Dergisi 5/10, 151-168.

YiLdiRIM 1989: R. Yıldırım, Urartu İğneleri, Ankara.

YILDIRIM and İPEK 2009: T. Y1ldırım, Ö. İpek, "2008 Y1lı Resuloğlu Eski Tunç Çağı Mezarlık Kazısı”, KST 31/3, 21-36.

WäFLER 1976: M. Wäfler, "Das Neuassyrische Felsrelief von Eğil”, Archäologischer Anzeiger 290-305.

WARTKE 1990: R. B. Wartke, Toprakkale Untersuchungen zu den Metallobjecten im Vorderasiatischen Museum zu Berlin, (=Schriften zur Geschichte und Kultur des Alten Orients 22), Berlin. 


\section{BİLCAN GÖKCE}

Orcid ID: 0000-0003-1213-7752

Iğdır Üniversitesi, Fen-Edebiyat Fakültesi, Sanat Tarihi Bölümü, Iğdır/TURKEY.

bilcan.g@gmail.com

\section{ESRA KAÇMAZ LEVENT}

Orcid ID: 0000-0003-2489-9527

Batman Üniversitesi Fen-Edebiyat Fakültesi, Arkeoloji Bölümü,

Batman/TURKEY.

arkeoesra@hotmail.com 

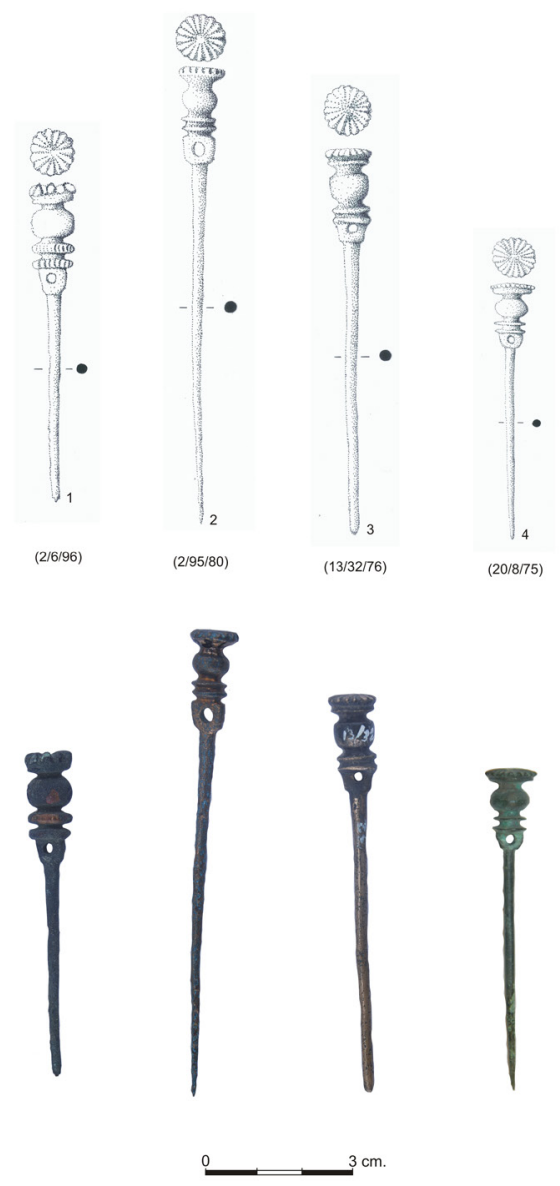

Fig. 1. Poppy-shaped headed pins.

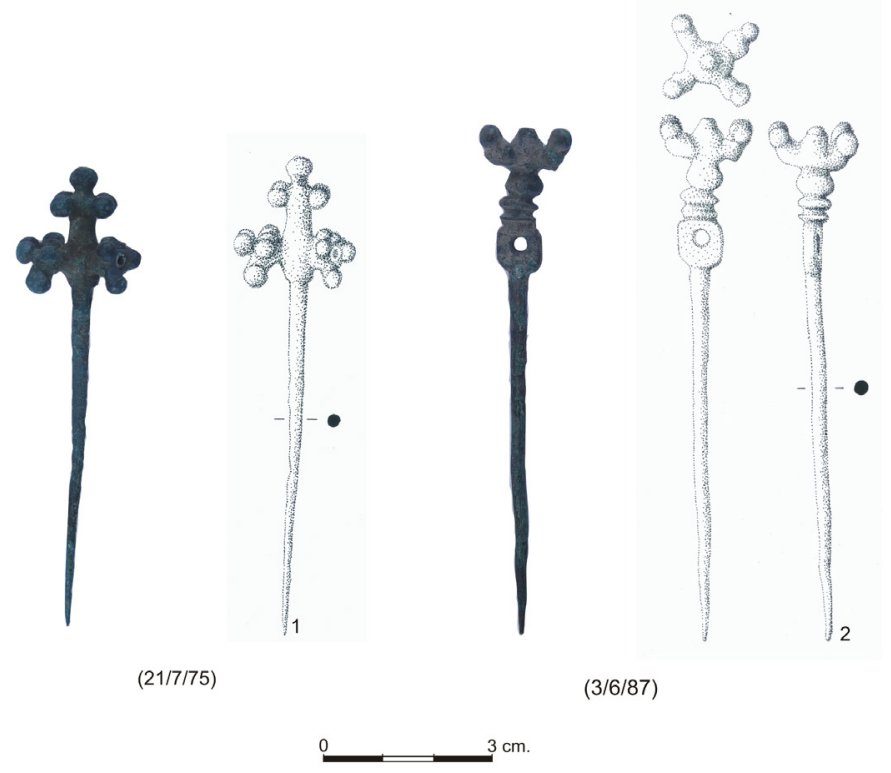

Fig. 2. Bud-shaped headed pins. 


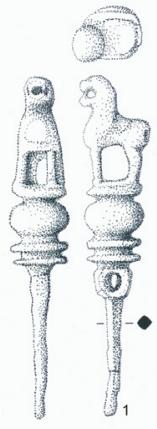

$(5 / 9 / 80)$

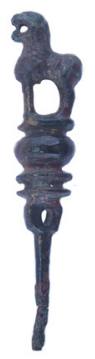

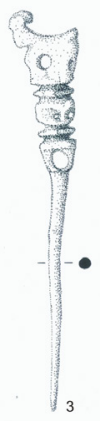

$(21 / 6 / 75)$

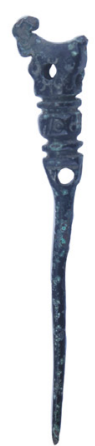

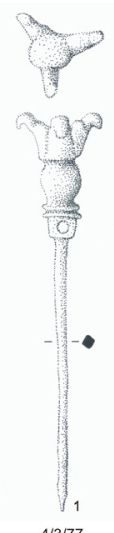

$4 / 3 / 77$
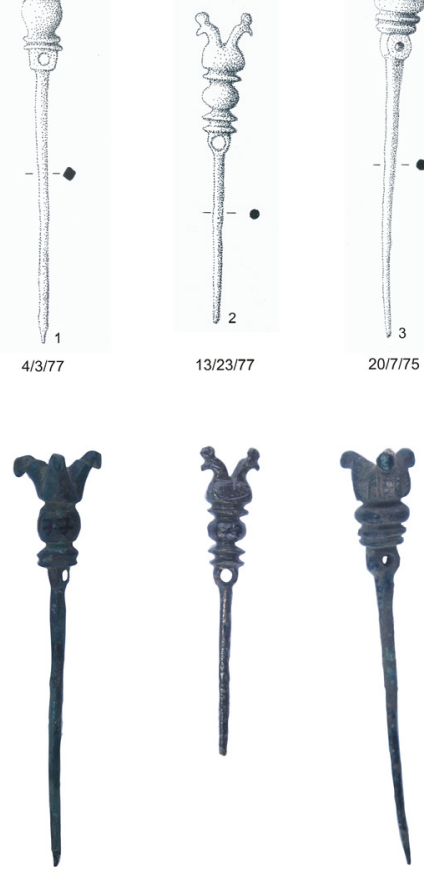

$3 \mathrm{~cm}$.

Fig. 4. Pins with animal protome.

Fig. 3. Animal-figure headed pins.

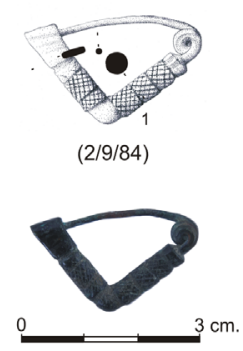

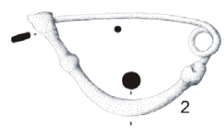

(2/262/08)
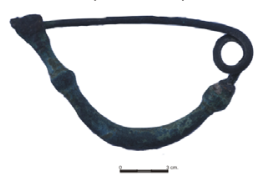

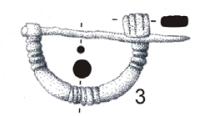

$(11 / 46 / 75)$

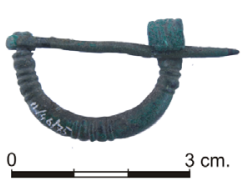

$3 \mathrm{~cm}$.

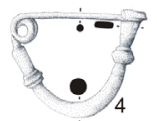

$(2 / 16 / 93)$
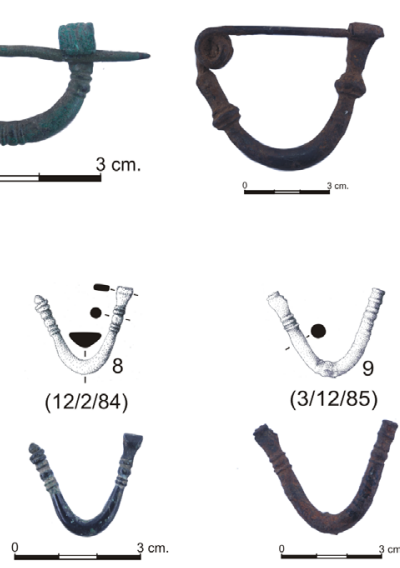

$(3 / 12 / 85)$

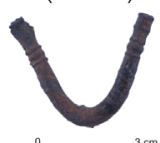

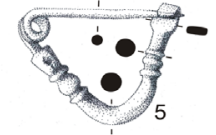

$(21 / 17 / 75)$

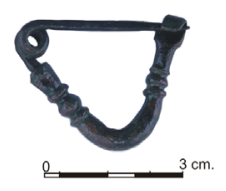

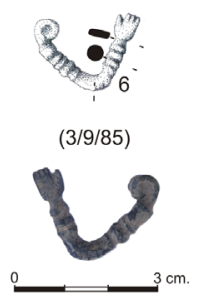

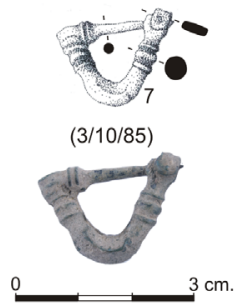

Fig. 5 Triangular fibula and semi-circular fibulae. 

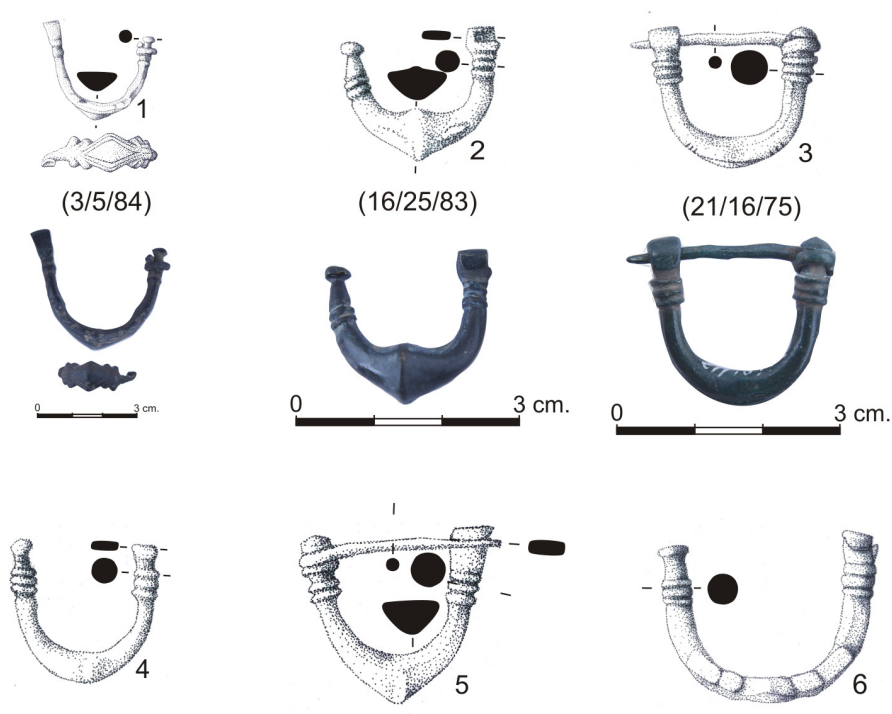

$(12 / 1 / 84)$
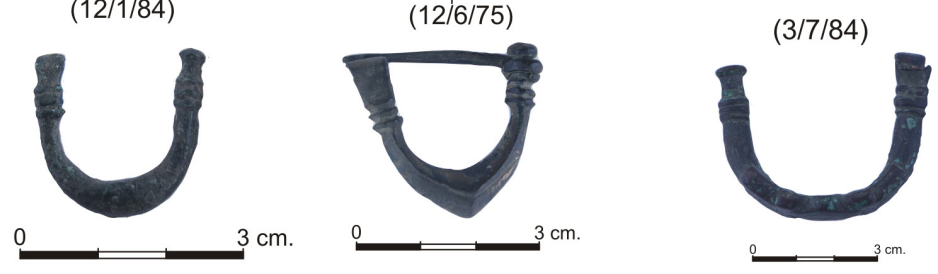

Fig. 6. Swollen-arch fibulae and horseshoe-shaped fibulae.

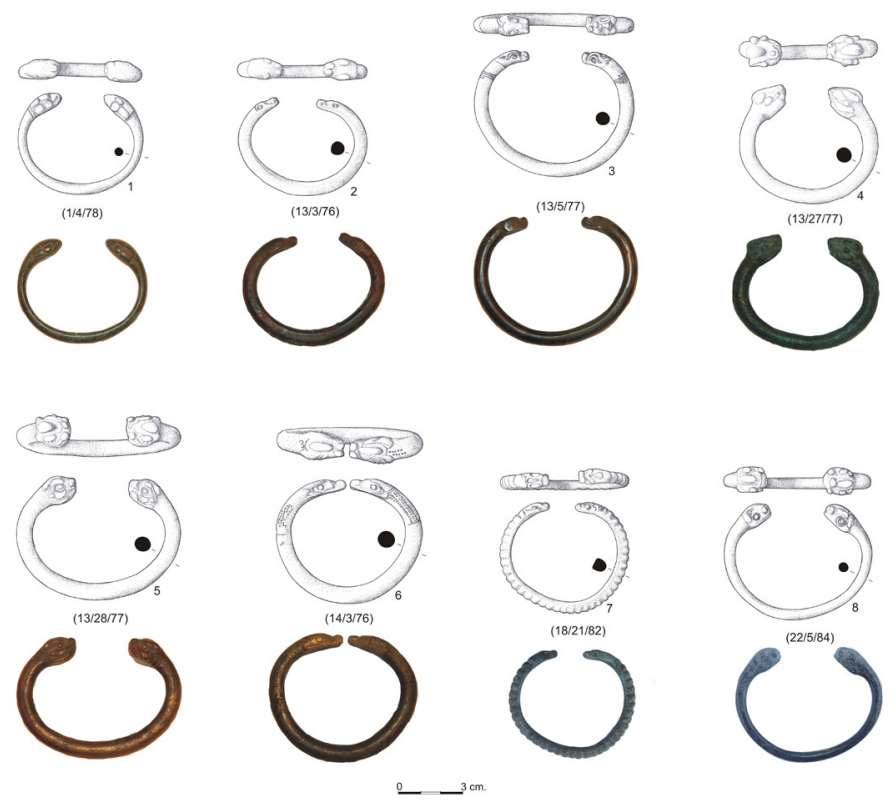

Fig. 7. Open-ended bracelets. 

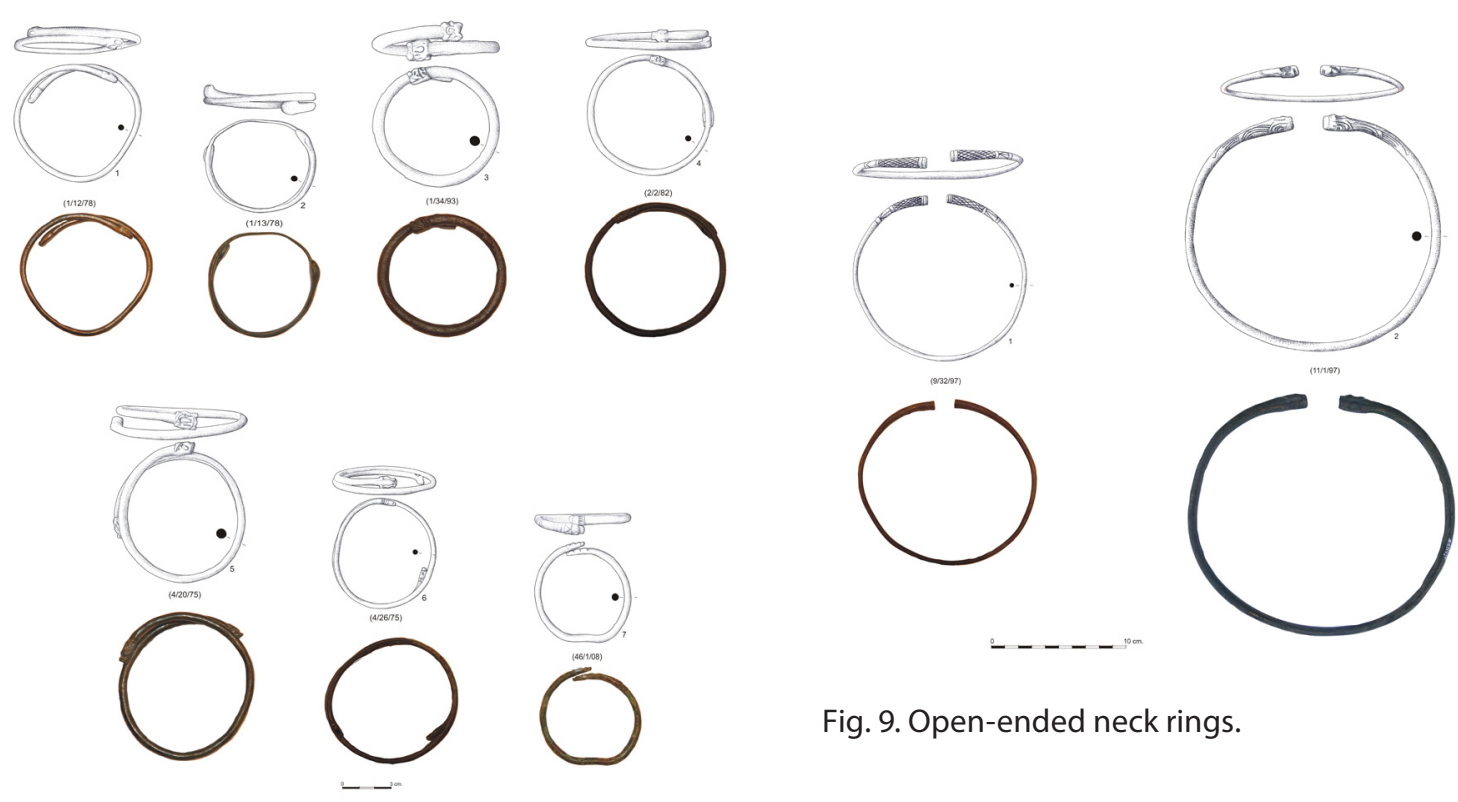

Fig. 9. Open-ended neck rings.

Fig. 8. Bracelets with overlapping ends.

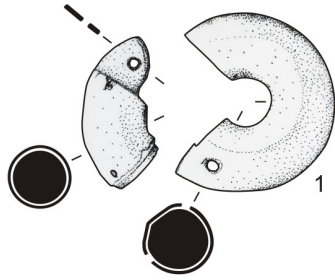

(15/35/75)
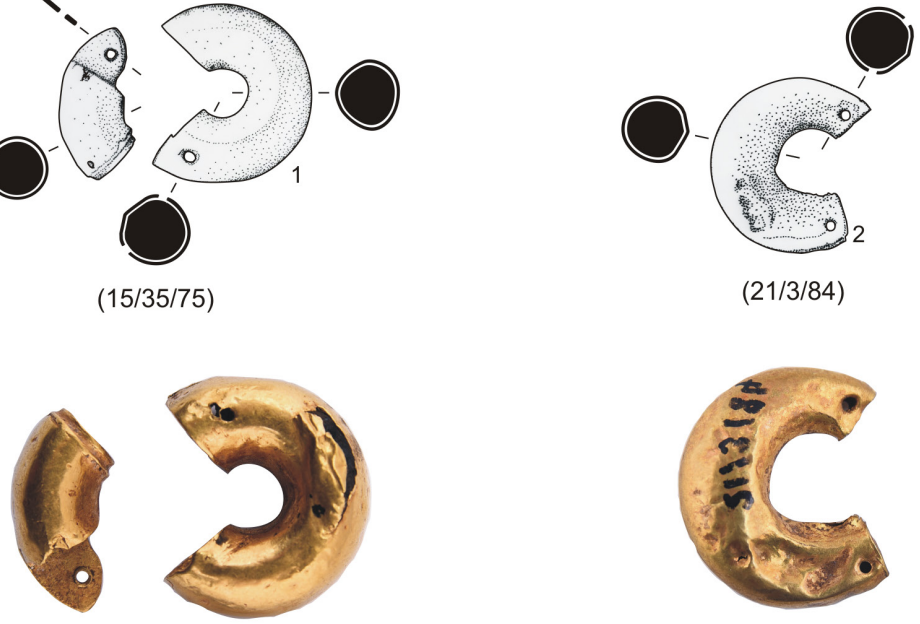

(21/3/84)
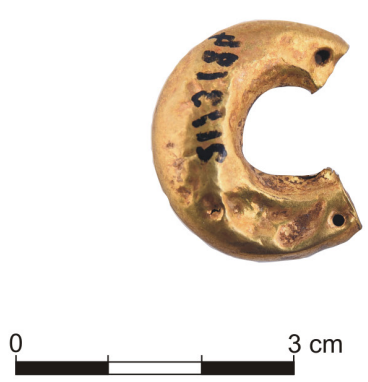

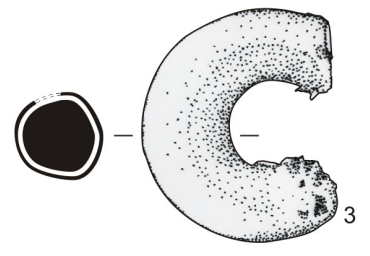

(21/2/84)

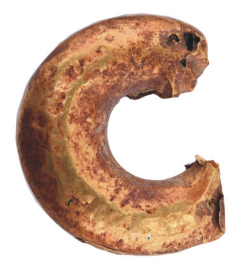

Fig. 10. Loop-shaped earrings. 